\title{
«La mejor colaboración artístico-literaria»: relaciones entre literatura e imagen en Saber Vivir
}

\section{"The best artistic-literary collaboration": relations between literature and image in Saber Vivir}

\author{
Federico Gerhardt \\ Universidad Nacional de La Plata, \\ CONICET, Argentina \\ http://orcid.org/0000-0002-9704-563X
}

DOI: https://doi.org/10.25032/crh.v7i12.9

Recibido: $7 / 4 / 2021$

Aceptado: 28/5/2021

Resumen. Entre 1940 y 1956, durante el auge de la industria cultural argentina, se publicó en Buenos Aires la revista Saber Vivir, creada por el diplomático y gourmet chileno José Eyzaguirre, que reunió a varias de las más importantes firmas del campo literario y artístico del medio siglo argentino. Joan Merli, editor, crítico y marchante de arte catalán exiliado se desempeñó como director artístico de la revista. Saber Vivir desarrolló un programa de orientación del consumo cultural, en términos amplios, dentro del cual la literatura ocupaba un lugar fundamental, a través de la publicación de diversos textos literarios y críticos. El artículo aborda las diferentes relaciones entre los textos de y sobre literatura, y las diversas imágenes que formaban parte del contexto de la revista, incluyendo las ilustraciones y fotografías que los acompañaban, las reproducciones de documentos, y los retratos de los autores.

Palabras clave: revistas culturales, historia de la edición, exilio español en Buenos Aires, décadas del cuarenta y cincuenta

\footnotetext{
Abstract. The magazine Saber Vivir, created by the Chilean diplomat and gourmet José Eyzaguirre, was published in Buenos Aires between 1940 and 1956, during the height of the Argentine cultural industry, and brought together several of the most important names in the literary and artistic field of that time. Joan Merli, editor, critic and Catalan art dealer in exile served as artistic director of the magazine. In that propitious context, Saber Vivir developed a program for the orientation of cultural consumption, in broad terms, in which literature occupied a central place, through the
} 
publication of various literary and critical texts. The article addresses the different relationships between literary texts and texts on literature, and the various images that were part of the context of the magazine, including the illustrations and photographs that shared a page with the texts, the reproductions of documents, and the portraits of the authors.

Keywords: cultural magazines, publishing history, Spanish exile in Buenos Aires, decades of 40's and 50's

\section{Coordenadas y programa}

El primer número de la revista Saber Vivir se publica en Buenos Aires en agosto de 1940 y su última entrega es el número 117, fechado en la navidad de 1956. Su extensa andadura, de poco más de dieciséis años, coincide, prácticamente, con el período que es considerado como la época de oro de la industria editorial argentina, uno de los momentos más prósperos para la edición revistas y, en términos más amplios, con el «auge de la industria cultural». ${ }^{1}$ En consonancia con este contexto, la revista se propuso formar el gusto del lector y orientarlo en el consumo de bienes culturales, tal como se deja ver en el texto de presentación del número inaugural, en el que se observa la pretensión de la revista de difundir o divulgar ciertos criterios de distinción relativos a diversos dominios, ${ }^{2}$ que van desde la alimentación y el vestuario hasta la literatura y las artes plásticas, esto es, cierto estilo de vida, aunque desconociendo su relación con un correspondiente nivel de ingresos:

Creemos, en primer término que saber vivir no es precisamente vivir entre oropeles

\footnotetext{
${ }^{1}$ Véanse, respectivamente: José Luis De Diego, «1938-1955. La "época de oro" de la industria editorial». Editores y políticas editoriales en Argentina (1880-200o). dir. José Luis de Diego. (Buenos Aires: Fondo de Cultura Económica, 2006), 91-123; y Jorge Rivera, El escritor y la industria cultural. (Buenos Aires: Atuel, 1998). Con respecto específicamente a la época de oro del mercado editorial, además del trabajo de José Luis de Diego, pueden verse estudios anteriores y posteriores como: María Teresa Pochat, «Editores y editoriales». El destierro español en América. Un trasvase cultural. comp. Nicolás Sánchez Albornoz. (Madrid: Siruela-Sociedad Estatal Quinto Centenario-Instituto de Cooperación Iberoamericana, 1991), 163-176; Leandro De Sagastizábal, La edición de libros en la Argentina. Una empresa de cultura. (Buenos Aires: Eudeba, 1995); Emilia de Zuleta, Españoles en la Argentina. El exilio literario de 1936. (Buenos Aires: Atril, 1999); Fernando Larraz, Editores y editoriales del exilio republicano de 1939. (Sevilla: Renacimiento, 2018); Alejandra Giuliani, Editores y política. Entre el mercado latinoamericano de libros y el primer, peronismo (1938-1955) (Temperley: Tren en Movimiento, 2018).

2 Afirma Pierre Bourdieu que ciertas formas de divulgación, como los semanarios «de calidad», pueden proporcionar «una satisfacción que debe también algo al sentimiento de la distinción», y que están «organizados para ofrecer a todos la sensación de estar a la altura de los consumos legítimos». Pierre Bourdieu, La distinción. Criterios y bases sociales del gusto. (Buenos Aires: Taurus, 2012), 379.
} 
deslumbrantes y fastuosidades ofensivas. Saber vivir es el arte de vivir con gusto, con satisfacción, con señorío, con cierto refinamiento que equivale a un deber imperativo en las clases poderosas y a un derecho innegable en las más pobres y humildes. El rico tiene el deber de vivir bien, y el pobre tiene el derecho de vivir bien, y es bueno anticipar que por pequeños que sean los jornales, una manera de vida bien orientada puede dar de sí gozos preciosos y placeres encantadores. Creemos asimismo que en el saber vivir hay mucho más que problemas materiales [...] Saber Vivir quiere ser dentro de cada hogar, una revista de lectura calma que para el pobre y el rico puede brindar una sugerencia útil que contribuya de algún modo al deleite, y al sosiego. (Saber Vivir, n. ${ }^{\circ}$ 1, p. 3)

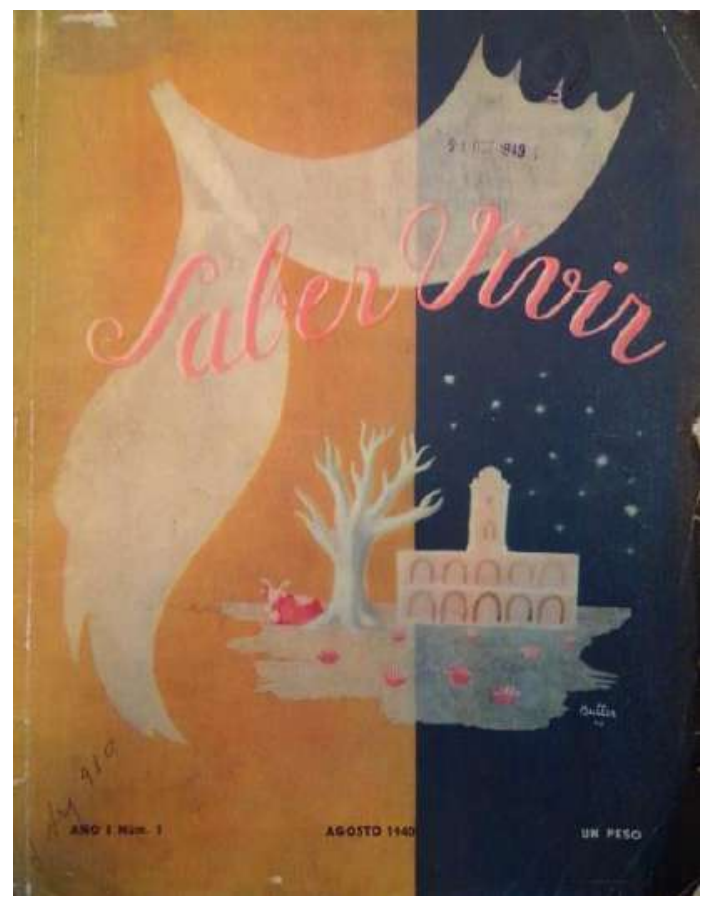

Figura 1. Cubierta del n. ${ }^{\circ} 1$ de Saber Vivir (agosto de 1940), por Horacio Butler.

El cierre de este texto inaugural y programático, llama la atención sobre una característica de la revista que la distingue - precisamente- de otras publicaciones periódicas, las cuales serían objeto de una lectura acelerada, callejera y, por lo tanto, adecuada al ritmo de la ciudad y en los breves ratos libres de trabajo. En cambio, Saber Vivir propone una lectura hogareña y sosegada, de acuerdo con la cual se construye el soporte material de la revista, con numerosas impresiones a color en papel de excelente calidad, en un formato de $35 \times 27 \mathrm{~cm}$, pero que, si se la compara con otras publicaciones contemporáneas y de dimensiones similares - como, por ejemplo, Correo Literario o Cabalgata, de Joan Merli (figuras 2 y 3)-,3 tenía no solo materiales de calidad

\footnotetext{
3 Correo Literario, publicada entre 1943 y 1945, y dirigida por Lorenzo Varela, Luís Seoane y Arturo Cuadrado, ha sido abordada en: Federico Gerhardt, «Independencia crítica y compromiso de empresa: Correo Literario (1943-1945) y el mercado editorial». Tiempos de papel. Publicaciones periódicas argentinas (siglos XIX y XX). coords. Verónica Delgado y Geraldine Rogers. (La Plata: FaHCE-UnLP, 2016), 263-284. http://www.libros.fahce.unlp.edu.ar/index.php/libros/catalog/book/78. Mar. 20, 2021. Cabalgata, editada de 1946 a 1948, encabezada y financiada por Joan Merli, con la dirección literaria de Varela y la artística de Seoane, ha sido estudiada en: Federico Gerhardt, «La revista
} 
superior, sino también una mayor cantidad de páginas - unas 64 en promedio, que podían aumentar en ocasiones especiales como festividades o aniversarios- con un lomo que hacía imposible doblar la revista en dos partes para llevarla con mayor comodidad o leerla sosteniéndola con una sola mano. Este soporte hacía de Saber Vivir, también a diferencia de otras publicaciones periódicas contemporáneas, un objeto durable, coleccionable, de acuerdo con lo que propone la misma revista en los avisos que invitan a obsequiar una colección de sus números «encuadernada con gusto», que podía conseguirse «en las mejores librerías».4

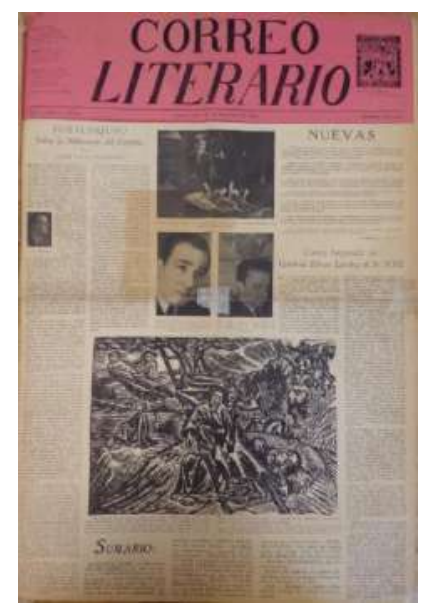

Figura 2

Tapa de Correo Literario (n. ${ }^{\circ}$ 3, Buenos Aires, 15 de diciembre de 1943)

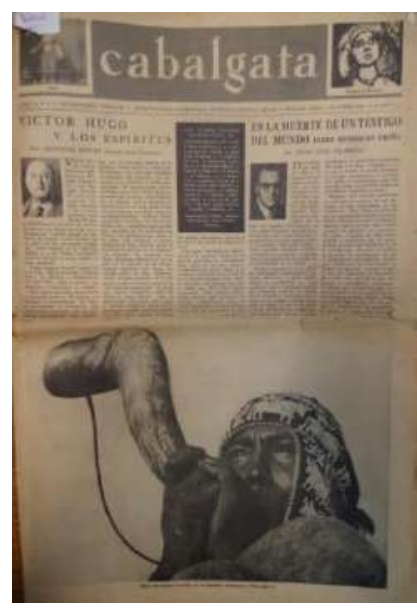

Figura 3

Tapa de Cabalgata (n. ${ }^{\circ}$ 1, Buenos Aires, 1 de octubre de 1946)

\section{El grupo directivo y la forma de la revista}

La revista Saber Vivir fue fundada y sostenida económicamente por José Eyzaguirre Herzl, un diplomático y gourmet chileno, residente en Buenos Aires, ciudad a la que había arribado tras dejar París en 1939, en vísperas de la que sería la Segunda Guerra Mundial.5 El propio Eyzaguirre fue el director general de la revista hasta el último número, siempre con Carmen Valdés como secretaria.

Cabalgata (1946-1948) y su mundo editorial». Revistas, archivo y exposición. Publicaciones periódicas argentinas del siglo XX. eds. Geraldine Rogers y Verónica Delgado. (La Plata: FaHCE-UNLP, 2019), 119144. https://www.libros.fahce.unlp.edu.ar/index.php/libros/catalog/book/148. Mar 20, 2021.

4 Además de librerías, la revista podía conseguirse en quioscos de revistas de la capital y del interior, pero también en otros puntos de venta como galerías de arte y grandes tiendas departamentales, de acuerdo con el anuncio que, desde sus primeros números, incluyó Saber Vivir en su primera página.

5 Las circunstancias que rodearon la concepción de la revista y el desarrollo inicial del proyecto, han sido abordadas en trabajos previos como: Jerónimo Ledesma, «La revista perdida. Saber Vivir, 1940-1956». La penosa manía de escribir. Ramón Gómez de la Serna en la revista Saber Vivir, 1940-1956. ed. Martín Greco. (Buenos Aires: Fundación Espigas, 2009). 35-55; y Federico Gerhardt, "Una revista transatlántica y trasandina. Redes intelectuales y editoriales en torno a Saber Vivir (1940-1956)». 
Eyzaguirre estaba acompañado, por un lado, en la dirección artística, por Joan Merli, editor y marchante de arte catalán exiliado en la Argentina, fundador y director, desde 1942, de Poseidón, editorial especializada en la edición de libros de arte, en colecciones como Aristarco o Críticos e Historiadores del Arte, y de literatura, en colecciones como Pandora o La Carabela en el Río. Por otro lado, la dirección literaria estaba a cargo de Álvaro de las Casas, gallego residente en Buenos Aires y uno de los fundadores y directores de la editorial Emecé, quien dejará la revista ya en el sexto número, desapareciendo con él su cargo, cuyas funciones, a partir de entonces, habrían sido asumidas en la práctica por el propio Merli.

Con respecto a la amplia nómina de colaboradores, pueden identificarse en ella, por un lado, un núcleo de escritores argentinos vinculados al consejo literario del diario La Nación - como Ricardo Rojas, Mariano de Vedia y Mitre, Manuel Mujica Láinezy al comité editorial de la revista Sur -Eduardo Mallea, María Rosa Oliver, Guillermo de Torre, entre otros-. Por otro lado, se advierte la presencia de un grupo de exiliados republicanos españoles vinculados con las revistas De Mar a Mar, ${ }^{6}$ Correo Literario y Cabalgata -todas contemporáneas a la publicación de Saber Vivir-, como los escritores Arturo Serrano-Plaja, Lorenzo Varela, Rafael Alberti, Rafael Dieste y María Teresa León, y los ilustradores Luís Seoane, Manuel Colmeiro y Ramón Pontones.7

La presencia de Merli resultó determinante en la realización material de Saber

Congreso Internacional «Chile Transatlántico» (Brown University-Universidad Católica de Chile, Santiago de Chile. 16-19 ag. 2016).

${ }^{6}$ De Mar a Mar, publicada entre 1942 y 1943, bajo la dirección de los secretarios Lorenzo Varela y Arturo Serrano-Plaja, ha sido analizada en: Federico Gerhardt, «Literatura, crítica y mercado del libro en De Mar a Mar (1942-1943): una lectura de la revista a la luz de las conexiones editoriales del exilio gallego en la Argentina», Madrygal. Revista de Estudios Gallegos, 20 (2017): 135-146.

7 Como explica García, entre estos grupos pueden establecerse otras conexiones con publicaciones periódicas contemporáneas, coincidentes en una toma de posición política contraria a los totalitarismos europeos y, más específicamente, a favor de la causa republicana en el caso español, como el diario Crítica, el periódico Unidad de la Agrupación de Intelectuales, Artistas, Periodistas y Escritores (AIAPE) y Argentina Libre. María Amalia García, «El señor de las imágenes. Joan Merli y las publicaciones de artes plásticas en la Argentina en los 40». Arte en revistas. Publicaciones culturales en la Argentina 1900-1950. dir. Patricia Artundo. (Rosario: Beatriz Viterbo, 2008): 173. A su vez, podría sumarse otras publicaciones vinculadas a algunos de los directivos y colaboradores, relacionadas con la difusión de la cultura gallega, como el periódico Galicia del Centro Gallego de Buenos Aires y su homónimo de la Federación de Sociedades Gallegas; y de la catalana, como Ressorgiment y Catalunya, respectivamente (véanse: Federico Gerhardt, «Asociacionismo gallego y mercado del libro en la Buenos Aires del medio siglo: dos proyectos editoriales de Luis Seoane», Madrygal. Revista de Estudios Gallegos, 18 (2015): 457-467; y Federico Gerhardt, «La revista Saber Vivir (Buenos Aires, 1940-1956) y la prensa de la emigración catalana en la Argentina: entre el consumo y la difusión culturales», Caderno de Letras. Revistas culturais latino-americanas dos séculos XX-XXI: teoria, circulação e suportes, 39 (2021 [en prensa]). 
Vivir, concebida inicialmente como una publicación dedicada a la gastronomía que fue expandiendo sus intereses hasta convertirse en una revista cultural en un sentido amplio, tal como recuerda José Eyzaguirre al cumplirse su primer aniversario y a raíz de su bautismo:

\begin{abstract}
Pasamos por toda la gama posible de la nomenclatura de prensa. Desde el nombre directo y sencillo de la «Buena Mesa», hasta la expresiva fórmula del «Savoir Vivre» francés. Pero, como no era propio que en una tierra, por tantos conceptos ligada a la hispanidad, cayéramos en un galicismo tan detonante, optamos por traducir el «Savoir Vivre» y quedamos en un castizo «Saber Vivir». Sin embargo, la traducción imponía una esfera mucho más amplia que la trazada en nuestra aspiración inicial. Ya no podíamos satisfacer el buen gusto solamente con recetas de buena cocina. Era preciso extender el recetario a la literatura, la pintura, la escultura, la historia anecdótica, las modas, la ebanistería, el sport elegante, la fotografía, las notas sociales, el arte -en suma- de saber vivir en todas sus formas. Y así llegamos a universalizar el alcance de la revista en ciernes. Quedaba lo más importante: darle forma, y una forma que, por su brillo y calidad respondiera a la alcurnia de las intenciones. [...] Fue entonces, señores, cuando el consorcio se enriqueció con la llegada de nuestro inteligente colaborador Juan Merli. El inspirado artista que dirigió en Barcelona la suntuosa y selecta revista «Arte» y otras de igual categoría, el mismo que tantos lauros consiguiera en famosas exposiciones de la ciudad mediterránea, vino a ser el ángulo que faltaba para triangulizar la base de la pirámide que nos proponíamos erigir (Saber Vivir, $\mathrm{n}^{\circ}$. 13, agosto de 1941, p. 53).
\end{abstract}

Desde su cargo directivo, cuyo peso en la revista aumentó con la temprana salida de Álvaro de las Casas, Merli habría incidido fuertemente en la importancia concedida a las imágenes en Saber Vivir a la hora de, en palabras de Eyzaguirre, dar forma a la revista. En relación con ello, cabe observar las claras diferencias entre el soporte material de Saber Vivir, que la vinculan con los magazines de décadas anteriores, ${ }^{8}$ y la austeridad de otras revistas, que fueron sus contemporáneas y con las que compartió varias firmas, como, por ejemplo, la citada Sur o Realidad (figuras 4 y 5). Con respecto a esta última, publicada también en Buenos Aires, entre 1947 y 1949, y en cuyas páginas escriben Guillermo de Torre y Eduardo Mallea -entre otros colaboradores en común, cabe destacar que su subtítulo, Revista de Ideas, refuerza el carácter intelectual y abstracto de la publicación, en contraste con la propuesta visual de Saber Vivir, en algunas de cuyas contratapas, a partir del número 15, se autodefine como «la mejor colaboración artístico-literaria del país» (figura 6).

\footnotetext{
8 Particularmente, como señala García, Saber Vivir se relaciona con Plus Ultra, con la que comparte además un programa de formación del gusto. María Amalia García, «El señor de las imágenes. Joan Merli y las publicaciones de artes plásticas en la Argentina en los 40». Arte en revistas. Publicaciones culturales en la Argentina 190o-1950. dir. Patricia Artundo. (Rosario: Beatriz Viterbo, 2008): 171. Sobre este aspecto de Plus Ultra, véase: Diana Wechsler, «Revista Plus Ultra: un catálogo del gusto artístico de los años veinte en Buenos Aires», Estudios e Investigaciones, 4 (1991): 199-209.
} 


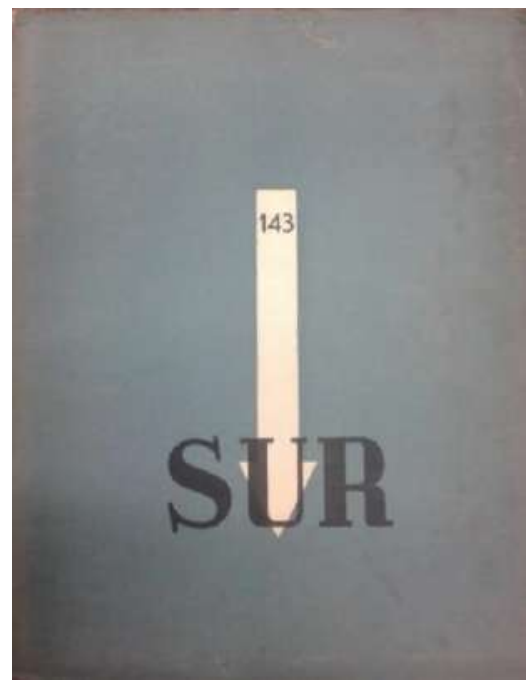

Figura 4 Cubierta de $\operatorname{Sur}\left(n{ }^{\circ}{ }^{143}\right.$, septiembre de 1946)

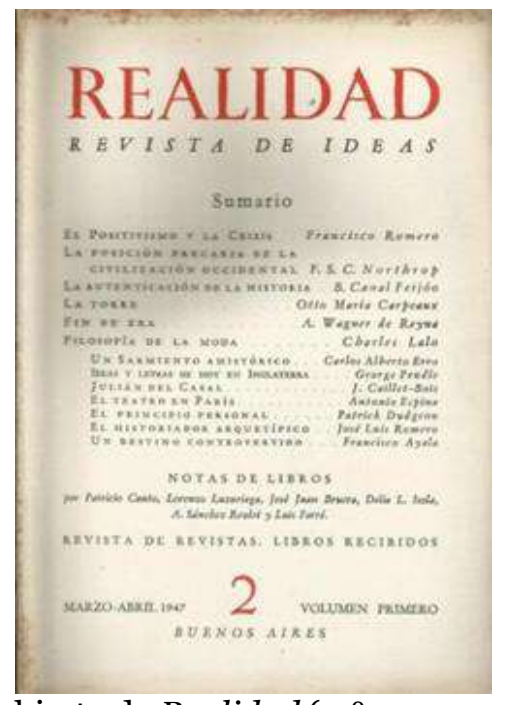

Figura 5 Cubierta de Realidad (n. ${ }^{\circ}$ 2, marzo abril de 1947)

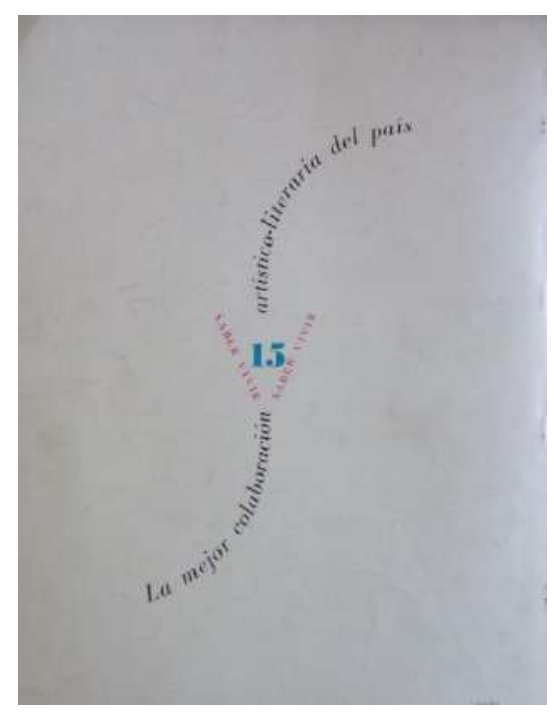

Figura 6. Contratapa del $n .{ }^{\circ} 15$ (octubre de 1941), con el lema «La mejor colaboración artístico literaria del país».

Precisamente, como una de las manifestaciones de la importancia concedida a la imagen en Saber Vivir, puede destacarse la presencia, junto con escritores como los nombrados en las líneas precedentes, de artistas plásticos que ilustran las tapas y el interior de la revista, como Antonio Berni, Horacio Butler, Raquel Forner, Jorge Larco, Raúl Soldi, Norah Borges, Gustavo Cochet y Juan Batlle Planas, entre otros (figuras 6, 7 y 8). Asimismo, a los también ya mencionados Seoane, Colmeiro y Pontones, se suman otros exiliados como Manuel Ángeles Ortiz y Andreu Dameson, quien además

9 Sobre la participación de Manuel Ángeles Ortiz en Saber Vivir, véanse Rodrigo Gutiérrez Viñuales, «"Siempre nuevo y audaz”. Manuel Ángeles Ortiz en Saber Vivir (1940-1944)». Manuel Ángeles Ortiz. Memoria de la Argentina. Rodrigo Gutiérrez Viñuales. (Granada: Diputación de Granada, 2017). 45-59. 
de ilustrar las páginas de Saber Vivir desde el primer número, ${ }^{10}$ relevó a Joan Merli en la dirección artística de la revista desde el número 29 hasta el 99, ${ }^{11}$ siguiendo la línea definida por su predecesor.

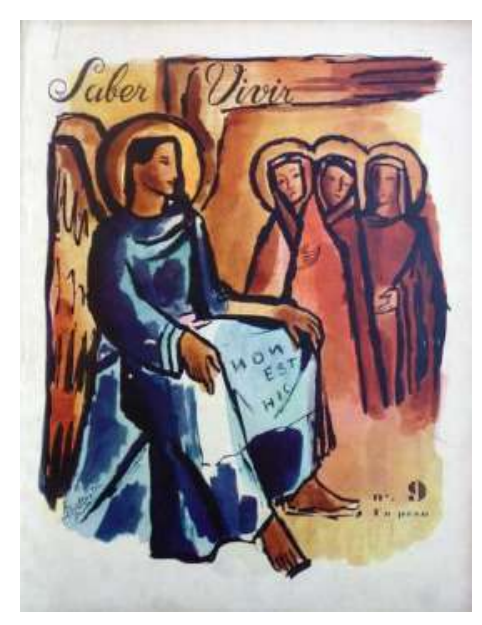

Figura 7

Tapa del $n .^{\circ} 9$ por Juan Batlle Planas

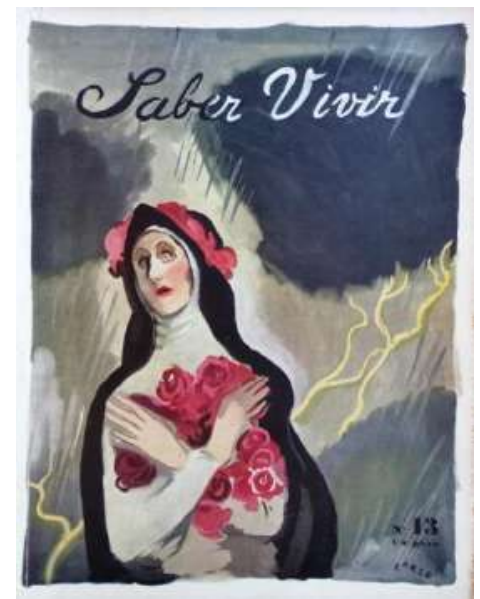

Figura 8

Tapa del $n .^{\circ} 13$ por Jorge Larco Forner

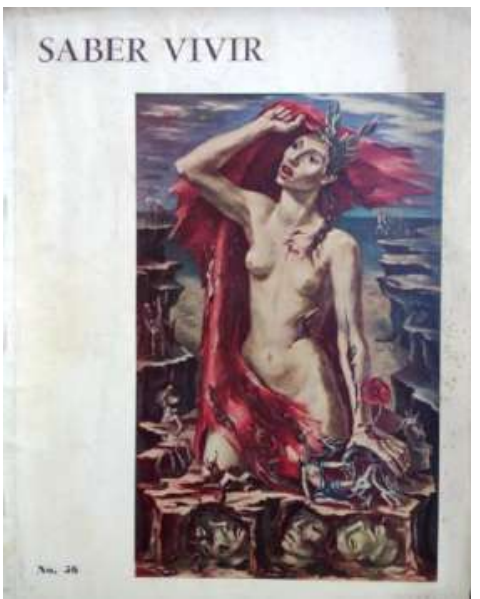

Figura 9

Tapa del $n .{ }^{\circ} 56$ por Raquel

Como señala María Amalia García (178), la presencia de la obra de estos artistas, no solo ilustrando determinados artículos, sino también ubicando sus obras en las tapas de la revista y siendo sus obras objeto de notas, puede leerse en relación con la actividad editorial de Merli a través de Poseidón. Sin embargo, además de este vínculo de su director artístico y del antedicho del director literario con Emecé, Saber Vivir participa de una red de relaciones editoriales que incluyen también, por ejemplo, a Dameson, quien ocupó puestos directivos en la Editorial Atlántida, y a muchos de sus colaboradores asiduos. Ilustradores como Seoane, que trabajó en el aspecto gráfico de las ediciones de Losada, Emecé y Poseidón, además de crear y dirigir Nova y Botella al Mar; y Manuel Colmeiro, artista plástico que ilustró numerosos libros de Emecé. Y escritores como Eduardo Mallea, quien dirigió para Emecé las colecciones El Navío, Cuadernos de la Quimera y Grandes Ensayistas; ${ }^{12}$ Rafael Dieste, director del

\footnotetext{
${ }^{10}$ En el n. ${ }^{\circ}$ 1, Andrés Dameson ilustra un calendario de agosto para el cuidado de frutales, huertas y jardines (n. ${ }^{\circ}$ 1, agosto de 1940, p. 10).

${ }^{11}$ Dameson deja la dirección artística de Saber Vivir para ocupar el cargo de Jefe del Departamento de Publicadiones Técnicas del Ministerio de Educación de la República Argentina. Sobre la trayectoria de Andrés Dameson, véase: Lluís Solà i Dachs y Jaume Capdevila. Andreu Dameson. Geni de la caricatura. Barcelona: Duxelm-Fundació Josep Irla, 2011.

${ }^{12}$ Considerando, además, su trayectoria editorial como autor, presenta una particularidad que De Diego llama el «caso Mallea»: «es el único autor que es publicado regularmente por todas las editoriales importantes [Losada, Sudamericana, Espasa Calpe y Emecé] [...] No sabemos las razones de esta
} 
Departamento Editorial de Atlántida y de dos de sus colecciones más populares y relevantes, la Biblioteca Billiken y la Colección Oro; y Guillermo de Torre, quien después de desvincularse de Espasa-Calpe participó en la fundación de Losada, donde fue asesor literario y director de algunas de sus colecciones más importantes y reconocidas, como La Biblioteca Contemporánea, La Pajarita de Papel, y Poetas de España y América, además de ser asesor editorial de Poseidón y uno de los autores más destacados de su catálogo. ${ }^{13}$

Considerando estas relaciones, resulta entendible que, dentro del programa de orientación del consumo de bienes culturales y de formación del gusto llevado adelante por Saber Vivir, tanto la literatura y la crítica como la actividad editorial ocupen un lugar fundamental, siendo uno de los campos en los que la revista pretendía guiar a su público, aun cuando, a diferencia de otras zonas de su incumbencia, no incluyera anuncios publicitarios de editoriales, excepto casos muy contados de, sobre todo, Poseidón.

La crítica de libros y las novedades editoriales tenían un espacio especial dentro de cada número. Las últimas páginas de cada entrega de Saber Vivir estaban ocupadas por la sección bibliográfica, primero llamada Memorandum y luego, simplemente, Libros. Estaba compuesta por reseñas breves y solía incluir, al final, la noticia de la aparición de nuevos títulos por medio de una lista bajo el título de «Libros recibidos», algunos de los cuales pasaban a ser reseñados en números posteriores. Tras algunos números sin dirección, pero con mayoría de reseñas firmadas por Joan de S’Agaró, seudónimo de Merli, y algunas entregas a cargo de Juana de Itúrbide, la sección bibliográfica fue dirigida hasta el penúltimo número, el 116, por Guillermo de Torre,

omnipresencia, pero podemos conjeturar algunas. Mallea era lo que hoy podríamos llamar un "agente literario": fue asesor editorial, dirigió tres colecciones para Emecé y tuvo a su cargo - como ya dijimosel suplemento cultural de La Nación entre 1931 y 1955. Pero también podemos suponer que era un escritor que jerarquizaba los catálogos: era entonces el prototipo de un escritor refinado y culto, un novelista profundo y un ensayista lúcido». José Luis De Diego, «1938-1955. La "época de oro" de la industria editorial». Editores y políticas editoriales en Argentina (1880-200o). dir. José Luis de Diego. (Buenos Aires: Fondo de Cultura Económica, 2006), 106-107.

${ }_{13}$ En trabajos previos se ha abordado algunos de los proyectos editoriales mencionados, en los que los exiliados de la Guerra Civil española han tenido una participación decisiva. Véanse: Federico Gerhardt, «Exiliados en la "edad de oro". Redes y políticas culturales del exilio gallego en el campo literario argentino de la década del 40: publicaciones periódicas, colecciones y editoriales», Revista Eletrônica da ANPHLAC, 19 (2015): 72-103; y Gerhardt, Federico, «La colección Poetas de España y América, de Editorial Losada: autores españoles y americanos en la conformación de su catálogo (1938-1955)». El orden de la cultura escrita. Estudios interdisciplinarios sobre inventarios, catálogos y colecciones. coords. Marina Garone Gravier et al. (Ciudad de México-Barcelona: Universidad Autónoma Metropolitana-Gedisa, 2020), 291-311. 
quien por lo general rubricaba todas las reseñas.

Según la intención declarada en sus inicios, «[e]n esta sección nos ocupamos de todos aquellos libros cuyos autores o editores tengan la gentileza de enviarnos un ejemplar. Pretendemos con ello contribuir, en la medida de nuestros alcance [sic], al mayor desarrollo de la cultura argentina» (n. ${ }^{\circ}$ 2, setiembre de 1940, p. 16). No obstante, la amplitud de esta declaración inicial - difícilmente puesta en práctica sin hacer una selección-, la sección bibliográfica atendía, con particular interés, a los títulos editados por los sellos con los que estaba relacionada Saber Vivir por medio de los integrantes de su grupo interno, como Losada, Poseidón, Emecé, Nova y Atlántida, y junto con ellas, otras como Sudamericana, Espasa-Calpe y El Ateneo. El mismo De Torre era, también, la firma más recurrente y destacada en los ensayos más extensos que la revista solía incluir por fuera de aquella sección.

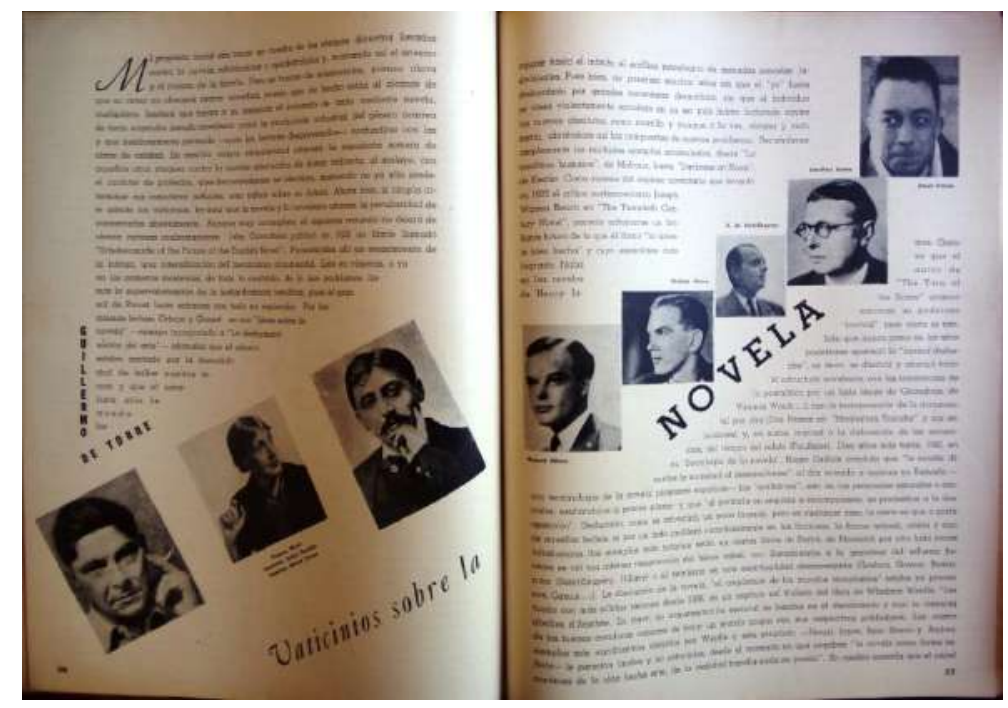

Figura 10. «Vaticinios de la novela» de Guillermo de Torre (n. ${ }^{\circ}$ 108, abril-junio de 1954, pp. 36-37), con los retratos fotográficos de Arthur Koestler, Virginia Woolf, Marcel Proust, Richard Hillary, Graham Green, Antoine de Saint-Exupery, Jean-Paul Sartre y Albert Camus.

\section{Literatura e imagen, de las ilustraciones a las fotografías}

Si bien la propuesta visual de Saber Vivir alcanzaba a los textos críticos, que podían cohabitar la página con diferentes imágenes, como las cubiertas de los libros reseñados en la sección bibliográfica, o los retratos fotográficos de los escritores cuyas obras se abordaran en los ensayos de mayor extensión (figura 10), la autodefinición de colaboración artístico-literaria es, en principio, más claramente identificable en la literatura que Saber Vivir solía articular con imágenes artísticas. Se trataba de diversos textos literarios, a cargo de reconocidos autores, los cuales cohabitaban la página, 
muchas veces, con ilustraciones realizadas por artistas acreditados, todos ellos, escritores e ilustradores que se movían en el campo cultural argentino, comprendiendo también a latinoamericanos residentes - sobre todo, chilenos-y exiliados - sobre todo, españoles - en la Argentina.

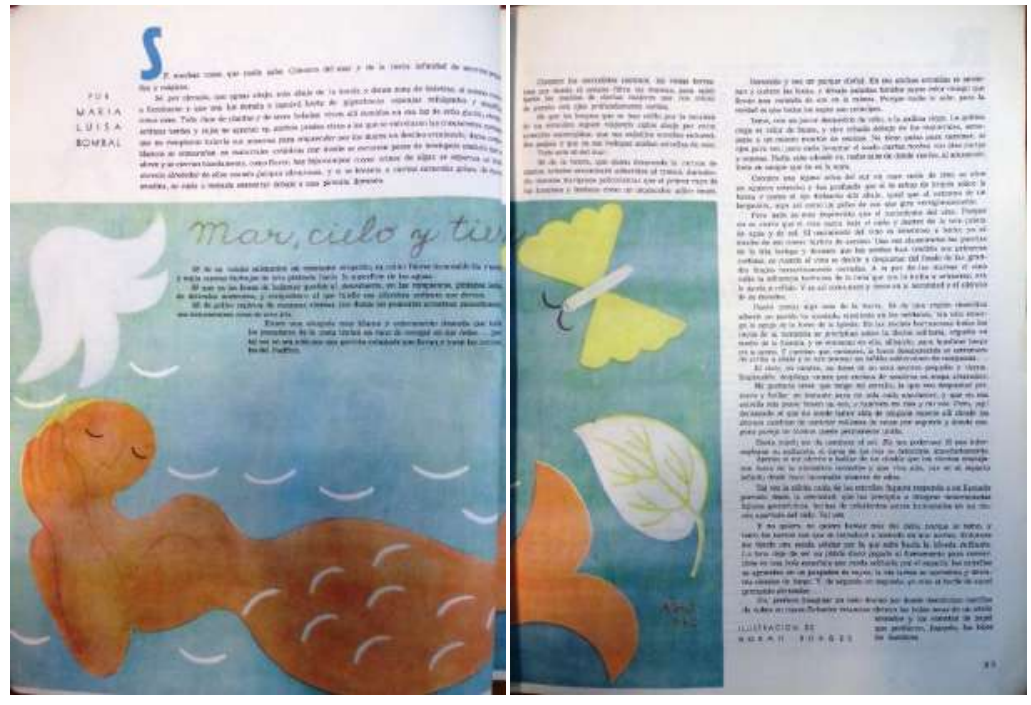

Figuras 11 y 12

Ya en el primer número puede encontrarse un ejemplo, con el texto de «Mar, cielo y tierra» de María Luisa Bombal, ilustrado por Norah Borges (n. ${ }^{\circ}$, agosto de 1940, pp. 34 y 35; figuras 11 y 12). A partir de entonces se multiplican las colaboraciones entre escritores y artistas, por ejemplo, Ricardo Rojas y Manuel Ángeles Ortiz (n. ${ }^{\circ}$ 24), la chilena Marta Brunet y Raquel Forner (n. ${ }^{\circ}$ 26), Rafael Alberti y Jorge Larco (n. $\left.{ }^{\circ} 35\right)$, Rafael Dieste y Manuel Colmeiro (n. ${ }^{\circ}$ 12), la española Rosa Chacel y Raúl Soldi (n. ${ }^{\circ} 57$ ), María Rosa Oliver y Horacio Butler ( . $^{\circ}{ }^{22}$ ), María Teresa León y Ramón Pontones ( $\mathrm{n}^{\circ}$ 13), Ramón Gómez de la Serna y Manuel Ángeles Ortiz (n. $\left.{ }^{\circ} 40\right)$ Lorenzo Varela y Luís Seoane ( $\left.\mathrm{n}^{\circ} 18\right)$, etc. (figuras $13,14,15$ y 16). A propósito de este último y de su destacada participación en Saber Vivir -sobre todo en sus primeros años-, cabe recordar que durante su trabajo en las editoriales antes referidas, entre sus incumbencias en el aspecto gráfico de las ediciones, se encontraba también la ilustración interior o de tapa de diferentes volúmenes. ${ }^{14}$

14 Además de las ilustraciones de tapa e interior en gran parte de los libros editados en colecciones o editoriales por él dirigidas, cabe destacar la ilustración de El proceso, de Franz Kafka, editado por Losada en 1939. 


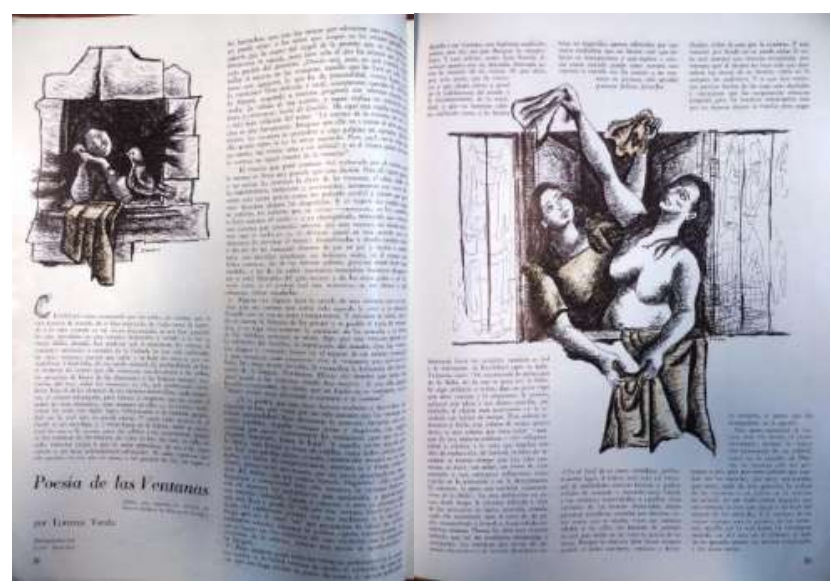

Figuras 13 y 14

«Poesía de las ventanas» de Lorenzo Varela. Ilustraciones de Luís Seoane (n. ${ }^{\circ}$ 18, enero de 1942, pp. 23-24)

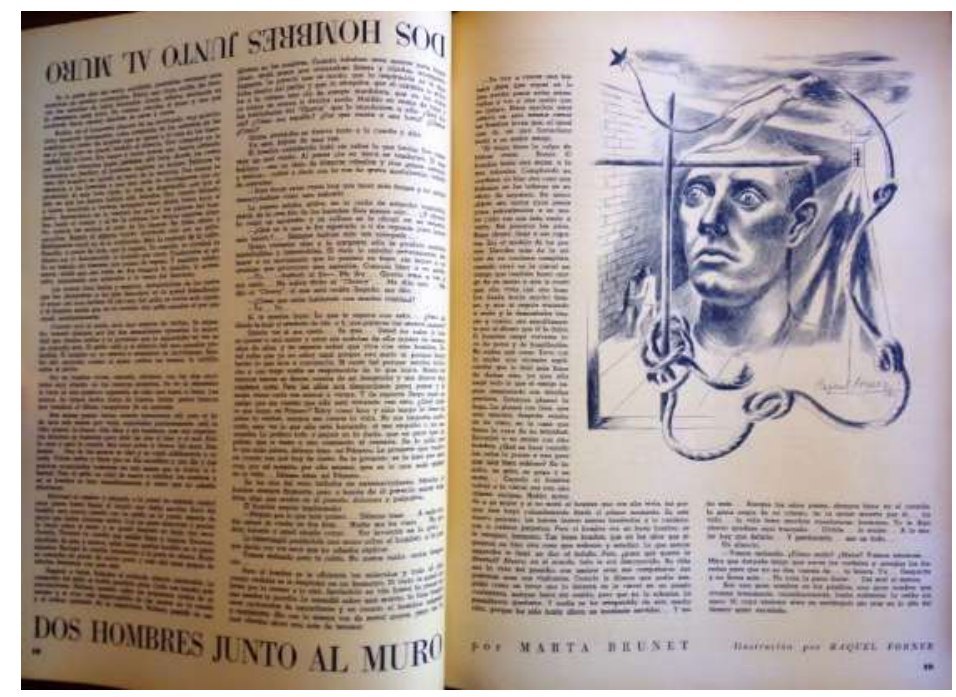

Figura 15. «Dos hombres junto al muro» de Marta Brunet. Ilustraciones de Raquel Forner (n. ${ }^{\circ}$ 26, setiembre de 1942, pp. 18-19)

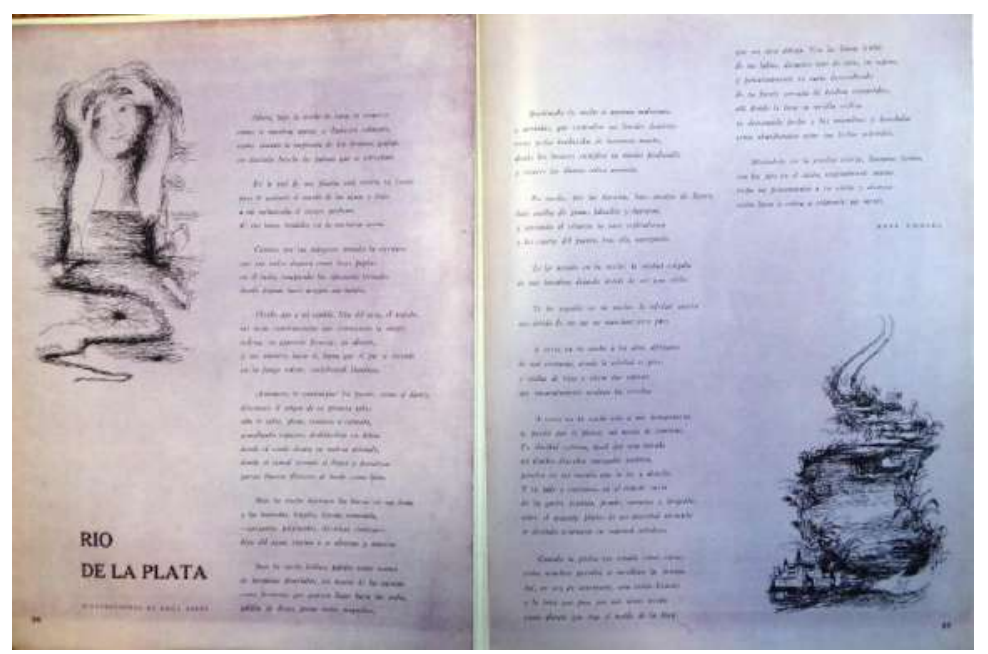

Figura 16. «Río de la Plata» de Rosa Chacel. Ilustraciones de Raúl Soldi (n. ${ }^{\circ}$ 57, setiembre 1945 , pp. 26-27) 
Junto con estas «colaboraciones artístico-literarias», Saber Vivir presentaba al lector diversos textos de creación firmados por destacados escritores que se movían en el campo literario argentino y en cuya edición el componente visual era igualmente relevante. Estas colaboraciones estaban constituidas, muchas veces, por adelantos de libros de próxima aparición, en general bajo el sello de alguna de las editoriales ya citadas, y, a falta de anuncios publicitarios específicos del rubro, podían funcionar como otra forma de promoción o publicidad, más o menos velada.

En este sentido resulta significativa una sección presente ya en el primer número de Saber Vivir, publicada con frecuencia irregular bajo el título de «Autógrafo de un libro en preparación». En cada entrega, en el espacio de una página, un escritor comenta brevemente el proyecto de escritura en que se encuentra trabajando. El comentario es acompañado, en cada caso, por el retrato fotográfico del autor y por la reproducción de un fragmento de la obra en proceso, ya sea una página manuscrita, mecanografiada o una prueba de imprenta corregida a mano por el mismo autor. En el primer número, quien aporta una página mecanuscrita con tachaduras y adiciones a mano, es Manuel Gálvez, un autor que en la década del cuarenta entra en el catálogo de Emecé, ${ }^{15}$ y adelanta un pasaje de su Vida de don Juan Manuel de Rosas, que ese mismo año de 1940 será editado por el propio Gálvez ${ }^{16}$ (n. ${ }^{\circ}$ 1, agosto de 1940, p. 55; figura 17). En el segundo llega el turno de Eduardo Mallea, que colabora con una página manuscrita de su novela La bahía del silencio, publicada también en 1940 por Editorial Sudamericana (n. ${ }^{\circ}$ 2, setiembre de 1940, p. 49; figura 18).

\footnotetext{
15 La colaboración de Gálvez en el primer número de Saber Vivir podría explicarse, más allá de su condición de autor conocido y reconocido en el campo de las letras, considerando que por entonces mantenía una relación de amistad con el todavía director literario de la revista, Álvaro de las Casas, de la que da cuenta en sus Recuerdos de la vida literaria. Manuel Gálvez, Recuerdos de la vida literaria (II). Entre la novela y la historia. En el mundo de los seres reales. (Buenos Aires: Taurus, 2003), 718719. En lo que respecta a la relación de Saber Vivir con Emecé, esta continuó aún después de que De las Casas dejara la dirección literaria de la revista, ya que la editorial es la encargada de la distribución de las dos ediciones (1943 y 1946) de El libro del buen comer. Secretos de la cocina revelados por P.P., de José Eyzaguirre, único libro sacado a la luz por la Editorial Saber Vivir, según se observa en el aviso publicado en diferentes números de la misma revista.

${ }^{16}$ En el pie editorial figura El Ateneo, que se encargó de su distribución.
} 


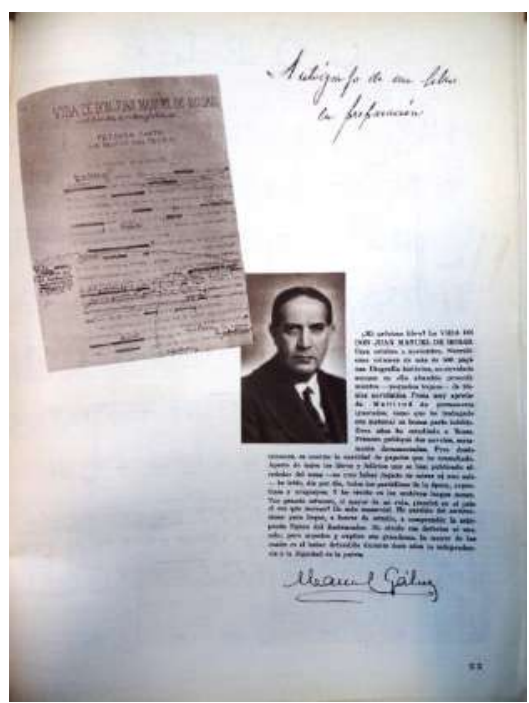

Figura 17

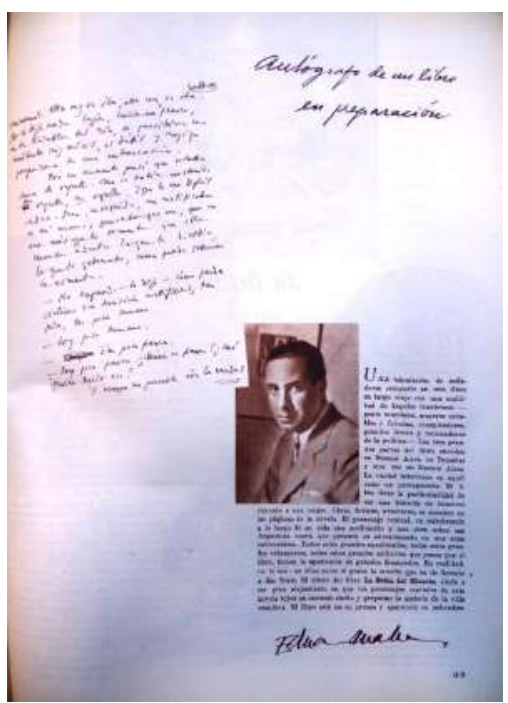

Figura 18

En las sucesivas entregas se dan cita fragmentos de libros diversos, no solo de literatura, sino también de historia del arte y de crítica literaria. Por ejemplo, y limitando el muestrario a dos de las firmas más importantes de Saber Vivir, en el número 15 (octubre de 1941, p. 62; figura 19) se reproduce una página de las galeradas corregidas a mano por Joan Merli, de su Picasso, editado en abril de 1942 por El Ateneo, acompañadas de un comentario sobre su estudio en prensa; y en el número 37 (agosto-setiembre de 1943, p. 87; figura 20) Guillermo de Torre da cuenta, en una breve nota, acompañada de una página manuscrita, de La aventura y el orden, un volumen de ensayos que publicará ese mismo año de 1943 la editorial Losada.

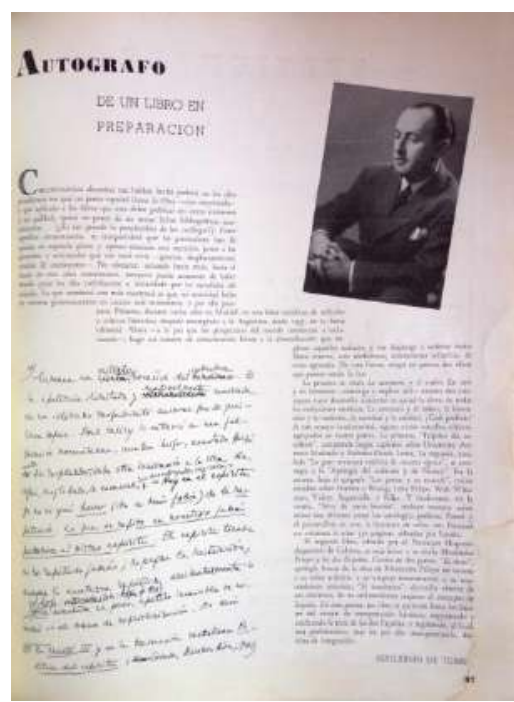

Figura 19

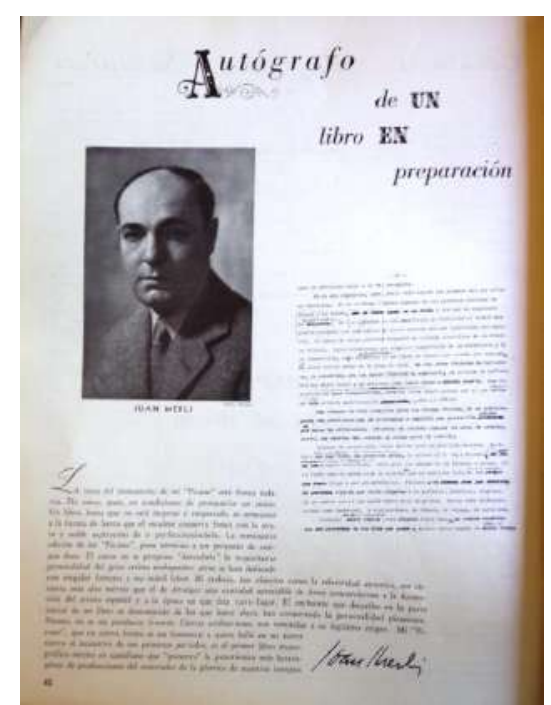

Figura 20

Resulta interesante, en la sección, la relevancia de la imagen en, al menos, dos 
aspectos. Por un lado, los documentos - autógrafos, pruebas, etc.- que se reproducen y exhiben en la página son parcial o totalmente ilegibles, sobre todo en el caso de la escritura manuscrita, y en ningún caso son transcriptos, por lo que puede decirse que importa en ellos más su visibilidad que su legibilidad. Por otro lado, en todos los casos, junto con el documento y su correspondiente comentario, se presenta el retrato fotográfico del autor, que se destaca en lo visual por contraste con los elementos que se encuentran en la misma página, y adquiere una marcada preponderancia en ella. No obstante, el caso más ilustrativo, precisamente, del uso del retrato fotográfico de un escritor en relación con el texto literario y su puesta en página puede encontrarse en el más asiduo de los colaboradores literarios de Saber Vivir, un caso que condensa -o, más bien, despliega, en virtud de sus numerosas colaboraciones- las diferentes formas del diálogo entre literatura e imagen antes referidas.

\section{Un caso ilustrativo: Ramón Gómez de la Serna}

Ramón Gómez de la Serna comienza su participación en Saber Vivir en el mismo número inaugural, invitado por la escritora chilena María Luisa Bombal, con un texto sobre las opíparas cenas del siglo XVII español, y colabora hasta el penúltimo número, correspondiente a la navidad de 1956, con el texto «La oración». ${ }^{17}$ Más allá de este primer contacto, del que queda testimonio en la correspondencia privada de Gómez de la Serna, cabe recordar además que él era el escritor predilecto de Joan Merli y que la admiración era correspondida por Gómez de la Serna, quien encontró en el catalán su editor ideal. Además de la correspondencia entre ambos, ${ }^{18}$ prueba de ello puede hallarse en los varios libros de Ramón en el catálogo de Poseidón -en varias de sus diferentes colecciones-, que incluye tanto reediciones como títulos nuevos, y, entre unos y otros, algunos de los más importantes de su producción: Don Francisco

\footnotetext{
17 Una selección de las colaboraciones de Gómez de la Serna en Saber Vivir ha sido editada por Martín Greco, con un completo y documentado estudio introductorio sobre la vida de Ramón Gómez de la Serna en la Argentina. Véase: Martín Greco, La penosa manía de escribir. Ramón Gómez de la Serna en la revista Saber Vivir, 1940-1956. (Buenos Aires: Fundación Espigas, 2009). En relación con el tema del presente trabajo, cabe señalar que el cambio de soporte -que, no obstante, incluye reproducciones de fotos y documentación personal-, al tiempo que vuelve accesibles ciertos escritos del autor, los priva necesariamente de su contexto de edición más inmediato -empezando por los elementos con que comparte página-, con todo lo que ello implica en cuanto a la producción de sentidos del texto en relación con las imágenes.

18 El intercambio epistolar entre el escritor y su editor ha sido estudiado en: Pura Fernández, «El epistolario de Ramón Gómez de la Serna y Joan Merli (1942-1950): hacia los libros creadores», Bulletin of Spanish Studies, LXXXVIII, 7-8 (2011): 287-298; y Laurie-Anne Laget, «Recrear «el verdadero lío de la vida»: programa estético y estrategia editorial detrás del ciclo ramoniano de las novelas de la nebulosa», Revista de Filología, 34 (2016): 135-153.
} 
de Goya y Lucientes, en 1942; Ismos, La viuda blanca y negra y Don Diego de Velázquez, en 1943; Oscar Wilde y José Gutiérrez Solana, en 1944; El novelista, en 1946; y El hombre perdido, en 1947.

En el total de noventa y seis contribuciones ramonianas en Saber Vivir, todos los textos comparten el espacio de la página con imágenes, cuya relevancia en el conjunto varía según el caso, conjugando la propuesta visual de la revista con el proyecto creador del propio escritor. ${ }^{19}$ En el terreno de la ilustración, además de las colaboraciones de Gómez de la Serna con ilustradores (véase supra), en algunos casos él mismo asume también esa tarea, como, por ejemplo, en «Alcance de las chimeneas» (n. ${ }^{\circ}$ 29, diciembre de 1942, pp. 40-43; figuras 21 y 22) y sus «Greguerías ilustradas» (n. ${ }^{\circ} 80$, julio-agosto de 1948, pp. 32-35; figuras 23 y 24), algo que ya había puesto en práctica en obras como Ramonismo (1921) y que repetiría en, por ejemplo, su Automoribundia (1948). Pero, a propósito de la autorreferencia y la autoexhibición de que dan cuenta títulos como los recién citados, ${ }^{20}$ y de la relación entre literatura e imagen observada en la sección Autógrafo de un libro en preparación, resulta más relevante referirse a los retratos fotográficos del escritor. ${ }^{21}$

\footnotetext{
19 Cabe señalar, aunque no analizar en profundidad en este trabajo, que incluso como crítico o historiador, Gómez de la Serna entiende la literatura en diálogo con la imagen, tal como explica, por ejemplo, en la reedición de su libro Ismos, publicada en Buenos Aires, en 1943, precisamente, por Poseidón: «Voy a hacer lo más prohibido por ciertos absolutistas teóricos, que es mezclar el nuevo arte y la literatura; pero del conjunto de esta herejía brotará una idea general de cómo es más verdad de lo que parece esta influencia recíproca» (p. 9).

${ }^{20}$ Los dos títulos son comentados por Guillermo de Torre. Al primero dedica un texto más extenso, sobre el que se volverá más adelante, titulado «Ramón Gómez de la Serna y sus bodas de oro con la literatura» (n. ${ }^{\circ}$ 111, enero-febrero-marzo de 1955, pp. 10-11), en el que afirma, sobre ese y todos los títulos que ha publicado hasta entonces: «la única denominación conjunta que les cuadra, el género a que todos pertenecen puede resumirse en una palabra: "Ramonismo"» (p. 11). El segundo es citado, con otros títulos ramonianos reseñados -Greguerías completas, Obras selectas, El incongruente y Cuentos de fin de año-, dentro de la sección "Libros", en «Suma y sigue de Ramón» (n. ${ }^{\circ} 80$, julio-agosto de 1948, p. 51), en que refiere un título alternativo para el volumen, tanto o más autorreferencial que el definitivo: "su copiosa autobiografía, en un principio, al parecer, titulada Ramón por Ramón, más que en definitiva, se llama, neológicamente Automoribundia».

${ }^{21}$ No cabe en el presente trabajo detenerse en la interesante cuestión de los retratos fotográficos de escritores, ni en la fotografía como tema en la obra de Ramón Gómez de la Serna. Sobre el primer asunto puede consultarse el catálogo de la exposición celebrada en 2014 en Madrid, editada por Publio López Mondéjar (2014), que dedica algunos pasajes a los retratos ramonianos. A la segunda cuestión se dedica un completo y reciente estudio: Humberto Huergo Cardoso, «El desahucio a la vista». Ramón Gómez de la Serna. El desahucio a la vista. Escritos sobre fotografía (1908-1954). ed. Humberto Huergo Cardoso (Madrid, Casimiro, 2019). 13-152.
} 

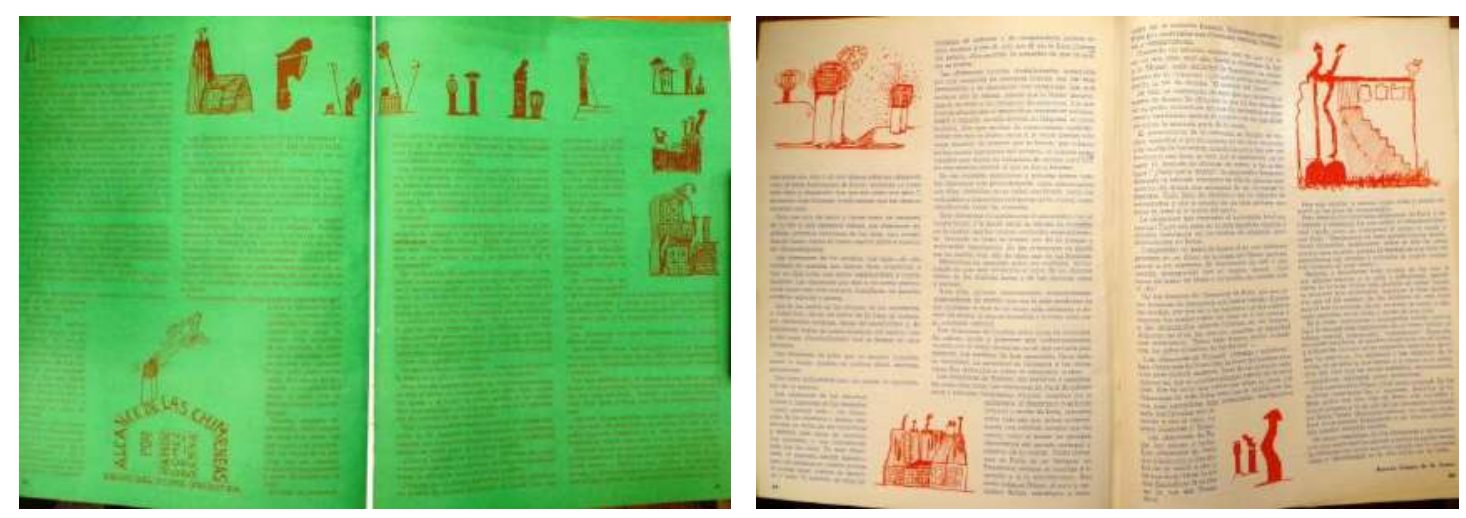

Figuras 21 y 22
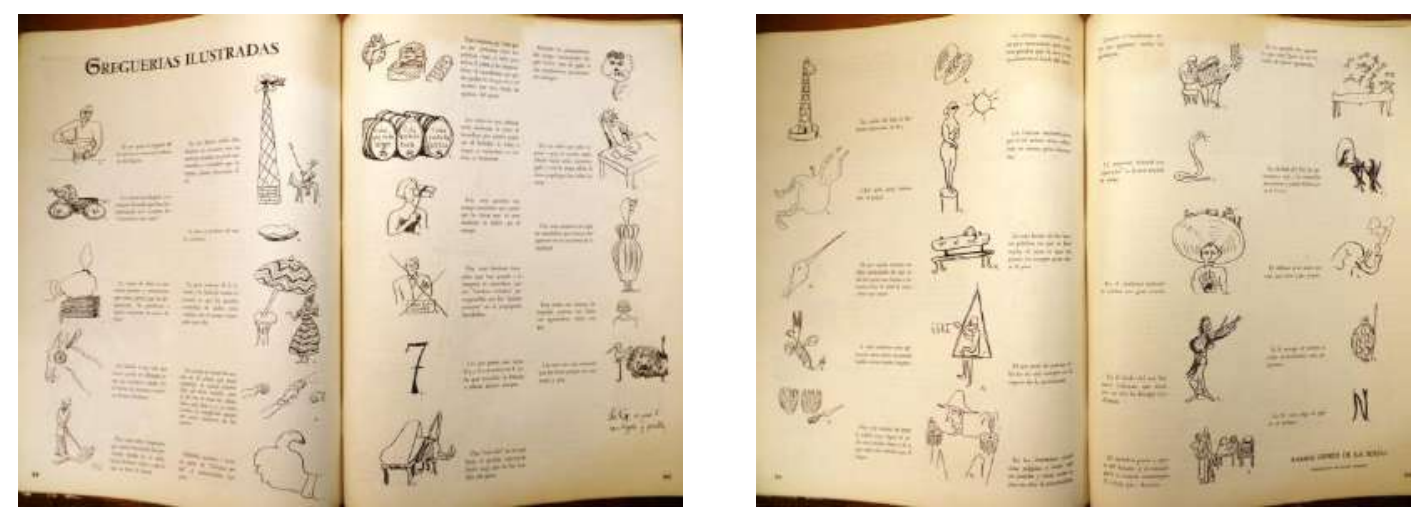

Figuras 23 y 24

Entre las colaboraciones de Gómez de la Serna en Saber Vivir no son pocos los retratos fotográficos de escritores, ya que suelen acompañar a sus correspondientes semblanzas escritas, que en su mayoría serán recogidas en los dos volúmenes de Retratos contemporáneos (1941) ${ }^{22}$ y Nuevos retratos contemporáneos (1945), editados por Sudamericana,23 como Miguel de Unamuno, Jacinto Benavente, Emilia Pardo Bazán, Vicente Blasco Ibáñez, Benito Pérez Galdós, Manuel y Antonio Machado, Pablo Neruda y Luigi Pirandello, entre otros (figuras 25 y 26). En este aspecto, no obstante, se destaca el propio Ramón, cuyas colaboraciones están muchas veces acompañadas por algunos de sus retratos fotográficos. Por ejemplo, puede encontrarse en un artículo titulado, precisamente, «Fotografías callejeras» (n. ${ }^{\circ}$ 54, 1945, pp. 25-26;

\footnotetext{
${ }_{22}$ A su vez, el libro es reseñado en Saber Vivir (n. ${ }^{\circ}$ 15, octubre de 1941, p. 63).

23 Ambos libros también contienen, al final, una serie de láminas en blanco y negro con retratos fotográficos de las personalidades incluidas en ellos. La segunda edición de Retratos contemporáneos (Sudamericana, 1944) lleva como ilustración de cubierta un dibujo de Gómez de la Serna conduciendo una especie de híbrido entre automóvil y cámara fotográfica.
} 
figuras 25-26), donde es retratado junto a su esposa Luisa Sofovich en cuatro oportunidades.

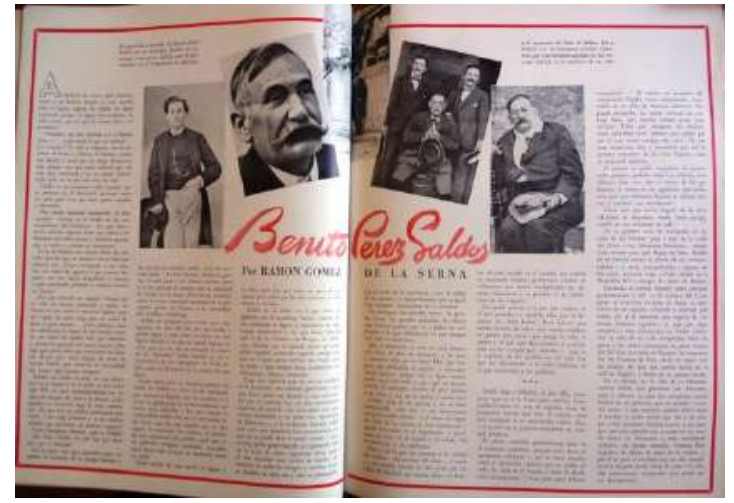

Figura 25

«Benito Pérez Galdós» (n. ${ }^{\circ} 30$, enero de 1943, pp. 20-21)

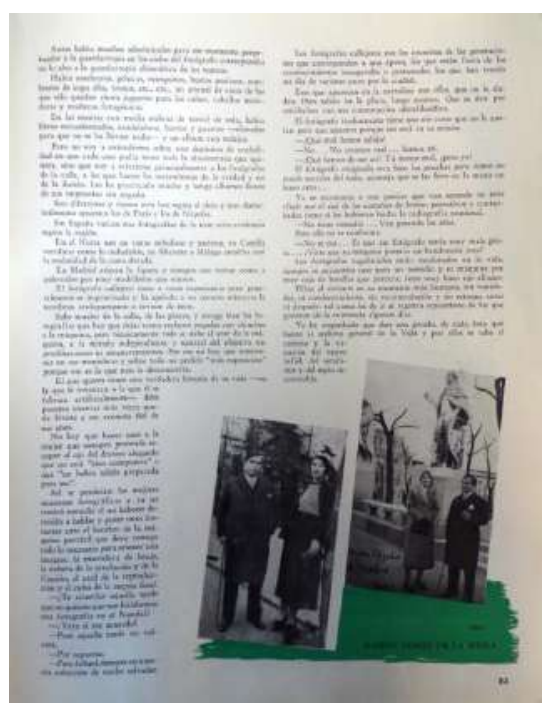

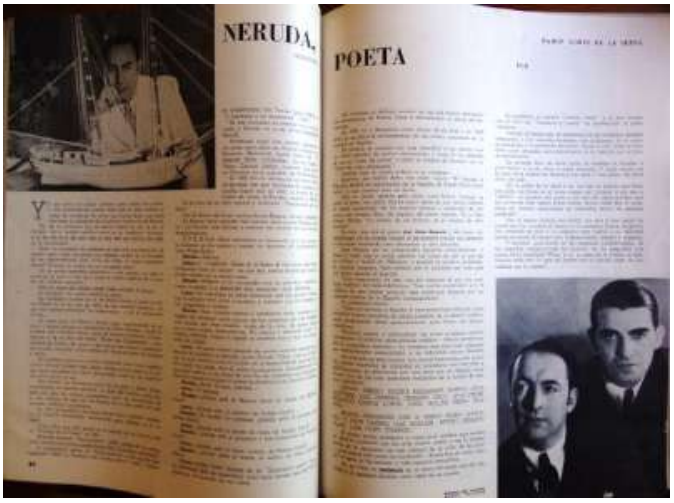

Figura 26

«Neruda, grandísimo poeta» (n. ${ }^{\circ}$ 37, agosto-setiembre de 1943 , pp. 44-45)

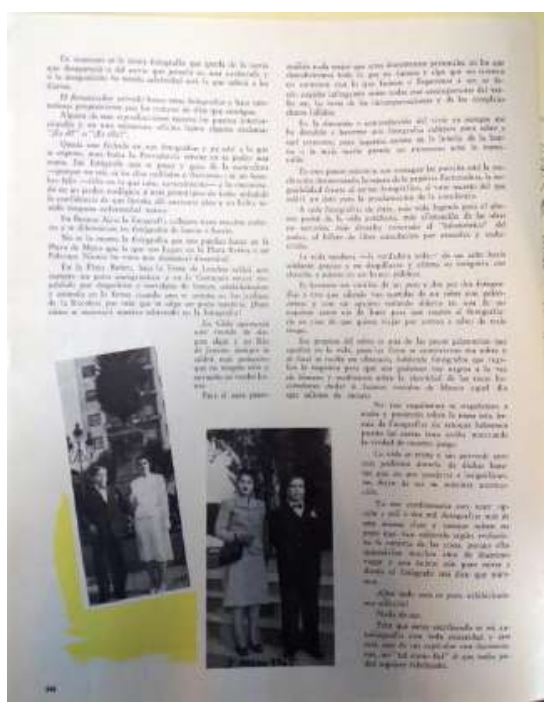

Figuras 27 y 28

Otra muestra es su «Despedida de la conferencia» (n. ${ }^{\circ}$ 109, julio-agostosetiembre de 1954, pp. 8-10; figuras 29, 30 y 31), donde además de dos dibujos de su autoría -también autorrepresentativos-el texto del artículo cohabita las páginas con varias fotografías del autor: una en la sala de conferencias de Emecé, acompañado por uno de sus directores, Mariano Medina del Río, y por la intelectual española María de Maeztu; otra, mientras dicta una conferencia en el Racing Club de Avellaneda; y un par en que está caracterizado para sendas conferencias en la Asociación Amigos del Arte, la primera como medio ser, oscurecida la mitad de su cuerpo, y la segunda como Napoleón Bonaparte, para dictar una conferencia en primera persona sobre el militar francés. En la última página, puede verse otras dos fotografías: una de Gómez de la Serna, ya no en el ámbito público de las conferencias, sino en la intimidad de su taller 
de escritor, en su escritorio de Buenos Aires bajo un retrato al óleo de Luisa Sofovich - pintado por él mismo-, y otra, junto a otra fotografía de un rincón de su mesa de trabajo en que puede verse, a su vez, el retrato de la poeta francesa Marceline Debbordes-Valmore.

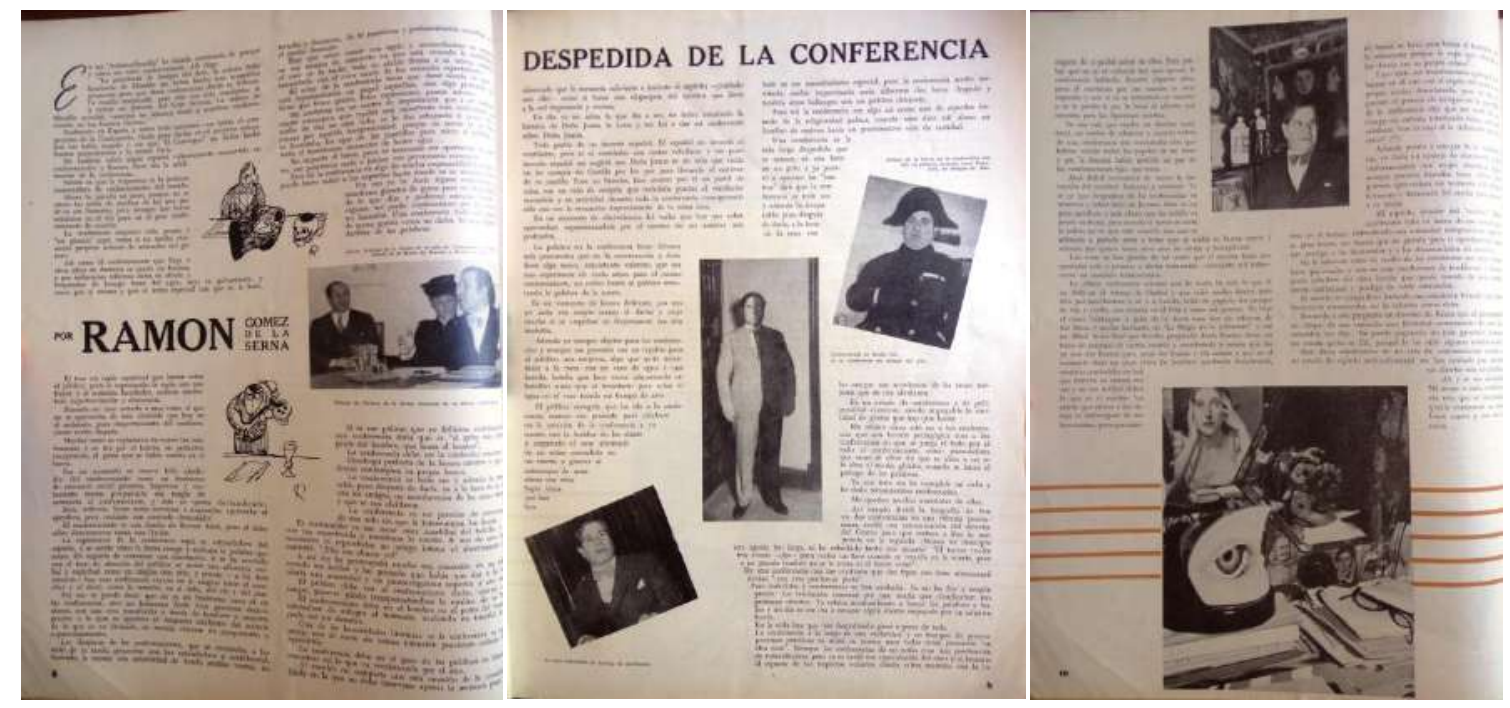

Figuras 29, 30 y 31

Estas dos últimas imágenes ya habían aparecido en «Estampario de aquí» (n. ${ }^{\circ}$ 72, 1947, pp. 29-31; figuras 32 y 33), otro ejemplo de la presencia de las fotografías del escritor en las colaboraciones literarias de Ramón Gómez de la Serna, quien en el mismo texto declara, en mayúsculas: «LA VIDA ES MIRAR», y luego agrega: «el hombre exige cosas que ver» (p. 30). Como respondiendo a ese mandato, además de las dos ya referidas, junto al texto se pone en página otras imágenes de distintos rincones del escritorio, ${ }^{24}$ al que el autor llama su «mundo gráfico» y otros dos retratos de Gómez de la Serna ambientados allí: uno con Luisa Sofovich y otro, el más grande, de «Ramón con la mano en el terráqueo luminoso», tras un montículo de libros que recargan su mesa de trabajo. También este retrato se repite, pero en una colaboración de otra de las firmas destacadas de Saber Vivir -y de Poseidón-.

${ }^{24}$ La mesa de los pisapapeles, el rincón donde se ve la porcelana romántica Los guantes que toca el piano, la pared donde cuelga «el espejo bombé más grande del mundo», y otra de las paredes decoradas con innumerables imágenes o, como las llama el autor, su «pinacoteca paretaria» (p. 31). 


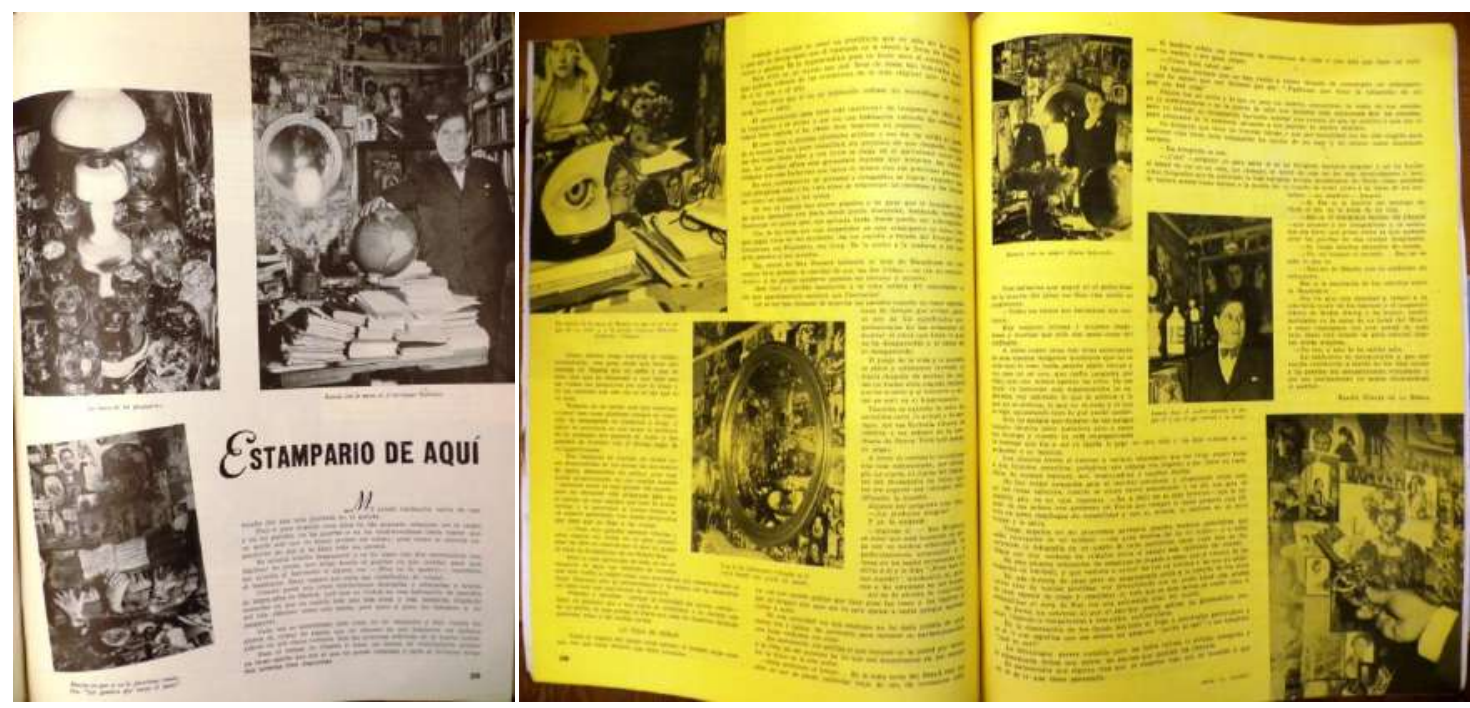

Figuras 32 y 33

Se trata del artículo «Ramón Gómez de la Serna y sus bodas de oro con la literatura» de Guillermo de Torre (n. ${ }^{\circ}$ 111, 1955, pp. 10-11; figura 34), a propósito de ese aniversario y, más específicamente, de «la “Antología” de Ramón que acaba de aparecer bajo el quíntuple sello de las más importantes editoriales argentinas» (p. 10). ${ }^{25} \mathrm{El}$ texto crítico reproduce en forma parcial la introducción del propio De Torre al libro Antología. 50 años de vida literaria, editado en 1955, en Buenos Aires, por Losada, Espasa Calpe Argentina, Poseidón, Emecé y Sudamericana, ${ }^{26}$ en cuya cubierta se expone la imagen de Gómez de la Serna (figura 35), al igual que, por ejemplo, en la sobrecubierta de la ya mencionada Automoribundia, editada en 1948 por Sudamericana (figura 36), en cuyo interior además se recogen todas las fotografías incluidas en los artículos de Saber Vivir citados, y dos de las tres colaboraciones. ${ }^{27}$

\footnotetext{
${ }^{25}$ En relación con el tema de este artículo, es interesante la definición -o, más bien, autodefinición- de Gómez de la Serna que cita De Torre: «Ramón una vez se ha definido a sí mismo más certeramente que nadie: se ha llamado "un mirador", y su obra un acervo de miradas, miradas y miradas» (p. 10).

${ }^{26}$ Tanto o más llamativo que el «caso Mallea» (véase nota 10) es este caso de Gómez de la Serna, quien no solo es editado por las editoriales más importantes del período - a las que se suma Poseidón-, sino que además uno de sus libros lleva juntos los cinco sellos.

27 «Fotografías callejeras» fue recogido en el capítulo 95 con el título «Sobre la verdad de las fotografías callejeras». «Estampario de aquí» fue incorporado en el capítulo 85 bajo el titulo más explícito de "Algo sobre las estampas que cubren las paredes, las puertas y los techos de mi casa».
} 


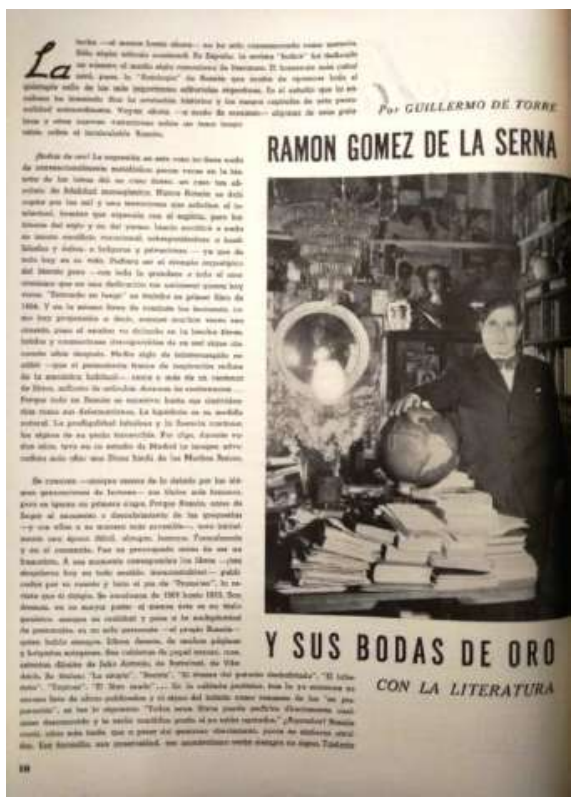

Figura 34

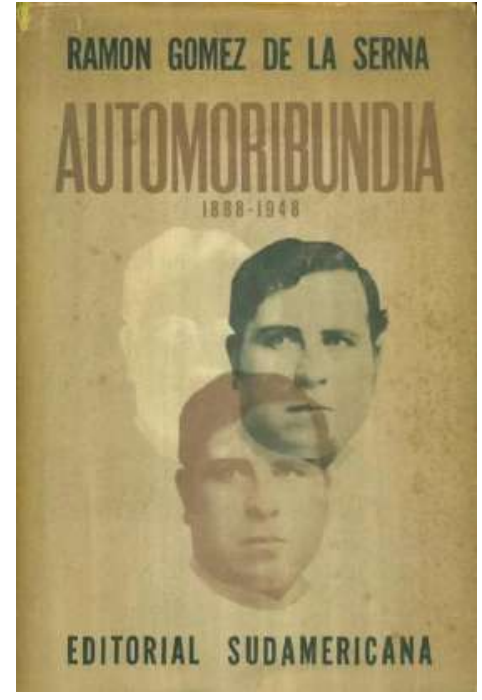

Figura 35

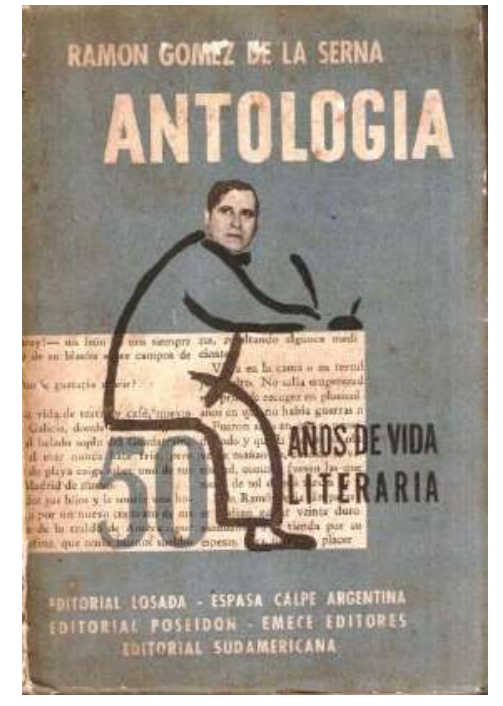

Figura 36

Casos como los arriba citados, los cuales se limitan al período abarcado por Saber Vivir, da cuenta de la vinculación entre ese peritexto editorial que -como señala Gérard Genette (7) - presenta la obra ante sus lectores para su consumo, en este caso, la cubierta de los libros, y la publicidad del campo editorial en sus diferentes formas, ya que ambos coinciden en la exposición de la imagen del autor. Así, por ejemplo, en la revista Cabalgata, financiada y encabezada por Joan Merli paralelamente a la publicación de Saber Vivir, el retrato fotográfico de Gómez de la Serna encabeza las publicidades de Poseidón (figuras 37 y 38). 

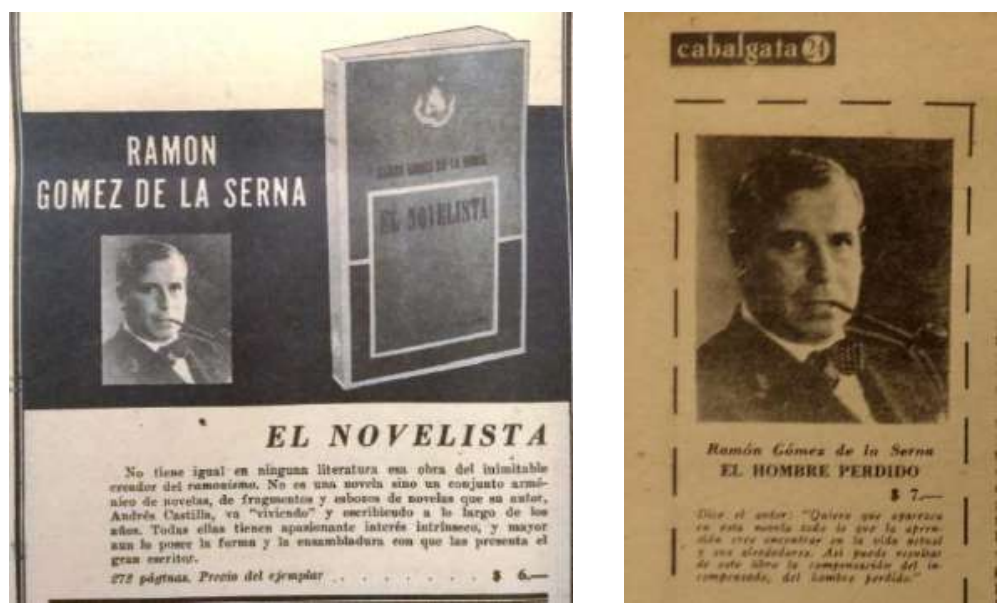

Figura 37

Publicidad de El novelista (Poseidón, 1946) en Cabalgata (n. ${ }^{\circ} 4$, 19 de noviembre de 1946, p. 10)

\section{Figura 38}

Publicidad de El hombre perdido (Poseidón, 1947) en Cabalgata (n. ${ }^{\circ}$ 7, 14 de enero de 1947 , p. 24)

En lo que respecta a la revista de Eyzaguirre, si bien prácticamente no incluye publicidad editorial, como se ha referido en líneas previas, además de las proliferación de fotografías del escritor en sus colaboraciones, de los adelantos de sus libros, ${ }^{28}$ y de la reseña de sus títulos editados por esos años, ${ }^{29}$ Saber Vivir incluye notas que lo retratan, en palabras e imágenes, en situaciones o poses relacionadas con su práctica literaria, como la titulada «La casa ilustrada de Ramón Gómez de la Serna» (n. ${ }^{\circ}$ 6, enero de 1941, p. 27; figura 39), que se abre explicando que «[d]amos una muestra del interior en que vive y escribe el literato español», al que define como alguien «del tiempo de las buenas reproducciones y de la vida gráfica». El texto comparte página con tres fotografías, una central, en la que se lo ve leyendo junto a su mujer -aunque distante-, y otras dos que revelan otras zonas de su escritorio, poniendo nuevamente en imagen el espacio de la escritura.

\footnotetext{
28 Por ejemplo -además de otros ya citados-: «Siempre el Romanticismo» (n. ${ }^{\circ} 16$, noviembre de 1941), parte del libro Mi tía Carolina Coronado (Emecé, 1942); o «Más claves de Solana» (n. ${ }^{\circ} 38$, octubre de 1943), luego en José Gutiérrez Solana (Poseidón, 1944). Más adelante, ambos libros serán, además, reseñados en Saber Vivir, en el n. ${ }^{\circ} 32$ (marzo de 1943) y en el n. ${ }^{\circ} 54$ (julio de 1945), respectivamente.

29 Aparte de las citadas en notas previas (véanse notas 20, 21 y 26), en la revista se publican reseñas de los siguientes libros: Greguerías 1940 (n. ${ }^{\circ}$ 2, septiembre de 1940), El doctor inverosímil (n. ${ }^{\circ} 16$, noviembre de 1941), Pombo (n. ${ }^{\circ}$ 18, enero de 1942), Doña Juana la Loca (n. ${ }^{\circ} 47$, setiembre de 1944), Norah Borges (n. ${ }^{\circ}$ 6o, febrero de 1946), Gollerías (n. ${ }^{\circ}$ 65, setiembre de 1946), Edgar Poe, el genio de América y Quevedo (n. ${ }^{\circ}$ 108, abril-mayo-junio de 1954).
} 


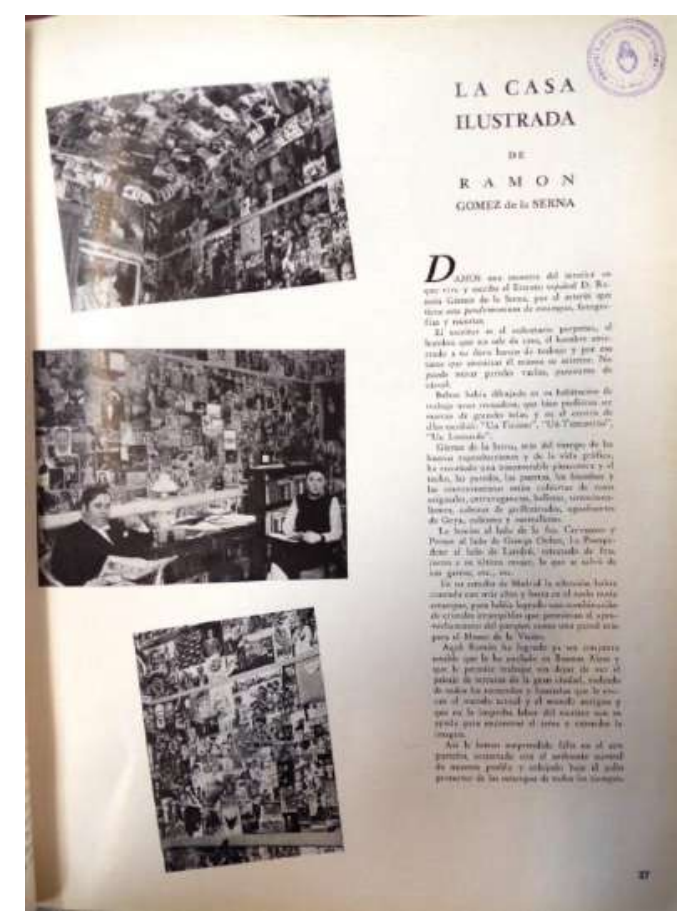

Figura 39

\section{A modo de cierre}

Tal como puede observarse en las líneas precedentes, en el contexto de la propuesta visual de la revista Saber Vivir y de su programa de orientación del consumo cultural y, más específicamente, del consumo de libros, la relación entre imagen y literatura en la revista cobra diversas formas que incluyen no solo la ilustración de un texto literario o la glosa de una imagen artística, sino que también las vincula con la actividad editorial.

A la luz de las diversas conexiones con el campo de la edición de libros en las que participan los integrantes del grupo directivo y varios de sus colaboradores más asiduos -que involucran a los sellos más importantes del período más próspero de la edición argentina- puede considerarse que las relaciones entre literatura e imagen en Saber Vivir forman parte de un entramado más amplio, que involucra a un conjunto de materiales diversos como adelantos de libros, reseñas, notas críticas, y otras formas de promoción y publicidad, más o menos explícitas.

Este entramado remite de nuevo a dos aspectos de la revista de Eyzaguirre referidos al comienzo del presente trabajo, estrechamente relacionados entre sí, a saber, su propuesta visual y sus lineamientos programáticos. Así, en relación con la formación del gusto y la orientación del consumo cultural que vertebran su programa, 
el mercado editorial incide en las diversas formas que cobra la exposición ${ }^{30}$ de textos, y de imágenes de textos y de autores, en Saber Vivir, y el reparto de espacios entre lo visible y lo legible en sus páginas.

En este sentido, las características materiales de Saber Vivir y su propuesta visual no la alejan del mundo del libro, sino que, por el contrario, la acercan y la integran en una red de relaciones dentro del campo de la edición, convirtiéndola también, con un leve retoque en su autodefinición, en una colaboración ${ }^{31}$ artísticoliteraria-editorial.

\section{Obras citadas}

\subsection{Fuentes}

\subsubsection{Revistas:}

Saber Vivir [Buenos Aires, 1940-1956]

\subsection{Bibliografía}

Bertho, Catherine, «Les concurrences». Histoire de l'édition française. IV. Le livre concurrencé 1900-1950. dirs. Roger Chartier y Henri-Jean Martin. París: Fayard, 1991.13-27.

Bourdieu, Pierre. La distinción. Criterios y bases sociales del gusto. Buenos Aires: Taurus, 2012.

De Diego, José Luis, «1938-1955. La “época de oro" de la industria editorial». Editores y políticas editoriales en Argentina (1880-2000). dir. José Luis de Diego. Buenos Aires: Fondo de Cultura Económica, 2006. 91-123.

De Sagastizábal, Leandro. La edición de libros en la Argentina. Una empresa de cultura. Buenos Aires: Eudeba, 1995.

Fernández, Pura, «El epistolario de Ramón Gómez de la Serna y Joan Merli (1942-

${ }^{30}$ A partir de las reflexiones de Philipe Hamon acerca de la literatura y la arquitectura, en Expositions. Littérature et architecture au XIXe siècle (París: José Corti, 1989), Geraldine Rogers retoma «el hilo de ese pensamiento de la exposición que excede la cuestión artístico-literaria, pero no puede dejar de incluirla», y propone considerar la revista «como dispositivo de exposición [...] como entorno diseñado para mostrar, como organización conjunta de lo visible y lo legible para la presentación racional de textos e imágenes». Geraldine Rogers, «Las publicaciones periódicas como dispositivos de exposición». Revistas, archivo y exposición. Publicaciones periódicas argentinas del siglo XX. eds. Geraldine Rogers y Verónica Delgado. (La Plata: FaHCE-UNLP, 2019). 12, 21.

${ }^{31}$ Catherine Bertho, a propósito de la historia de la edición en la primera mitad del siglo XX, señala que la competencia entre escrito e imagen a partir del predominio de esta última desde principios de siglo, determina en las décadas siguientes una separación cada vez mayor entre la edición de libros y la edición de prensa -fundamentalmente, en formas con preponderancia de lo visual, como los magazines-, no obstante la cual, se desarrollan diversas formas de «colaboración» [collaboration] entre prensa y libros. Catherine Bertho, «Les concurrences». Histoire de l'édition française. IV. Le livre concurrencé 190o1950. dirs. Roger Chartier y Henri-Jean Martin. (París: Fayard, 1991). 18. 
1950): hacia los libros creadores», Bulletin of Spanish Studies, LXXXVIII, 7-8 (2011): 287-298.

Gálvez, Manuel. Recuerdos de la vida literaria (II). Entre la novela y la historia. En el mundo de los seres reales. Buenos Aires: Taurus, 2003.

García, María Amalia, «El señor de las imágenes. Joan Merli y las publicaciones de artes plásticas en la Argentina en los 40». Arte en revistas. Publicaciones culturales en la Argentina 1900-1950. dir. Patricia Artundo. Rosario: Beatriz Viterbo, 2008. 167-199.

Genette, Gérard. Umbrales. Ciudad de México: Siglo Veintiuno Editores, 2001.

Gerhardt, Federico, «Asociacionismo gallego y mercado del libro en la Buenos Aires del medio siglo: dos proyectos editoriales de Luis Seoane», Madrygal. Revista de Estudios Gallegos, 18 (2015): 457-467. https://revistas.ucm.es/index.php/MADR/article/view/48569/45373

Gerhardt, Federico, «Exiliados en la 'edad de oro'. Redes y políticas culturales del exilio gallego en el campo literario argentino de la década del 40: publicaciones periódicas, colecciones y editoriales», Revista Eletrônica da ANPHLAC, 19 (2015): 72-103. http://revistas.fflch.usp.br/anphlac/article/view/2360/2195

Gerhardt, Federico, «Independencia crítica y compromiso de empresa: Correo Literario (1943-1945) y el mercado editorial». Tiempos de papel. Publicaciones periódicas argentinas (siglos XIX Y XX). coords. Verónica Delgado y Geraldine Rogers. La Plata: FaHCE-UNLP, $2016.263-284$. http://www.libros.fahce.unlp.edu.ar/index.php/libros/catalog/book/78

Gerhardt, Federico, «Una revista transatlántica y trasandina. Redes intelectuales y editoriales en torno a Saber Vivir (1940-1956)». Congreso Internacional «Chile Transatlántico». Brown University-Universidad Católica de Chile, Santiago de Chile. 16-19 ag. 2016.

Gerhardt, Federico, «Literatura, crítica y mercado del libro en De Mar a Mar (19421943): una lectura de la revista a la luz de las conexiones editoriales del exilio gallego en la Argentina», Madrygal. Revista de Estudios Gallegos, 20 (2017): 135-146.

https://revistas.ucm.es/index.php/MADR/article/viewFile/56227/50886

Gerhardt, Federico, «La revista Cabalgata (1946-1948) y su mundo editorial». Revistas, archivo y exposición. Publicaciones periódicas argentinas del siglo XX. eds. Geraldine Rogers y Verónica Delgado. La Plata: FaHCE-UnLP, 2019. 119-144.

https://www.libros.fahce.unlp.edu.ar/index.php/libros/catalog/book/148

Gerhardt, Federico, «La colección Poetas de España y América, de Editorial Losada: autores españoles y americanos en la conformación de su catálogo (19381955)». El orden de la cultura escrita. Estudios interdisciplinarios sobre inventarios, catálogos y colecciones. coords. Marina Garone Gravier et al. Ciudad de México-Barcelona: Universidad Autónoma Metropolitana-Gedisa, 2020. 291-311.

Gerhardt, Federico, «La revista Saber Vivir (Buenos Aires, 1940-1956) y la prensa de la emigración catalana en la Argentina: entre el consumo y la difusión culturales», Caderno de Letras. Revistas culturais latino-americanas dos séculos XX-XXI: teoria, circulação e suportes, 39 (2021 [en prensa]). 
Giuliani, Alejandra. Editores y política. Entre el mercado latinoamericano de libros y el primer, peronismo (1938-1955). Temperley: Tren en Movimiento, 2018.

Greco, Martín. La penosa manía de escribir. Ramón Gómez de la Serna en la revista Saber Vivir, 1940-1956. Buenos Aires: Fundación Espigas, 2009.

Gutiérrez Viñuales, Rodrigo. «'Siempre nuevo y audaz'. Manuel Ángeles Ortiz en Saber Vivir (1940-1944)». Manuel Ángeles Ortiz. Memoria de la Argentina. Rodrigo Gutiérrez Viñuales. Granada: Diputación de Granada, 2017. 45-59.

Hamon, Philipe. Expositions. Littérature et architecture au XIXe siècle. Paris: José Corti, 1989.

Huergo Cardoso, Humberto. «El desahucio a la vista». Ramón Gómez de la Serna. El desahucio a la vista. Escritos sobre fotografía (1908-1954). ed. Humberto Huergo Cardoso. Madrid, Casimiro, 2019.13-152.

Laget, Laurie-Ann, «Recrear «el verdadero lío de la vida»: programa estético y estrategia editorial detrás del ciclo ramoniano de las novelas de la nebulosa», Revista de Filología, 34 (2016): 135-153.

Larraz, Fernando. Editores y editoriales del exilio republicano de 1939. Sevilla: Renacimiento, 2018.

Ledesma, Jerónimo. «La revista perdida. Saber Vivir, 1940-1956». La penosa manía de escribir. Ramón Gómez de la Serna en la revista Saber Vivir, 1940-1956. ed. Martín Greco. Buenos Aires: Fundación Espigas, 2009. 35-55.

López Mondéjar, Publio. El rostro de las letras. Escritores y fotógrafos en España desde el Romanticismo hasta la Generación de 1914. Madrid: Comunidad de Madrid-Acción Cultural Española-Real Academia Española, 2014.

Pochat, María Teresa, «Editores y editoriales». El destierro español en América. Un trasvase cultural. comp. Nicolás Sánchez Albornoz. Madrid: Siruela-Sociedad Estatal Quinto Centenario-Instituto de Cooperación Iberoamericana, 1991. 163176.

Rivera, Jorge. El escritor y la industria cultural. Buenos Aires: Atuel, 1998.

Rogers, Geraldine, «Las publicaciones periódicas como dispositivos de exposición». Revistas, archivo y exposición. Publicaciones periódicas argentinas del siglo $X X$. eds. Geraldine Rogers y Verónica Delgado. La Plata: FaHCE-UNLP, 2019. 1127. https://www.libros.fahce.unlp.edu.ar/index.php/libros/catalog/book/148

Solà i Dachs, Lluís y Jaume Capdevila. Andreu Dameson. Geni de la caricatura. Barcelona: Duxelm-Fundació Josep Irla, 2011.

Wechsler, Diana «Revista Plus Ultra: un catálogo del gusto artístico de los años veinte en Buenos Aires», Estudios e Investigaciones, 4 (1991): 199-209.

Zuleta, Emilia de. Españoles en la Argentina. El exilio literario de 1936. Buenos Aires: Atril, 1999. 